\title{
Going public via special purpose acquisition companies: Frogs do not turn into princes
}

\author{
Johannes Kolb ${ }^{\mathrm{a}}$, Tereza Tykvová ${ }^{\mathrm{b}, *}$ \\ a University of Hohenheim, Wollgrasweg 49, 70599 Stuttgart, Germany \\ b University of Hohenheim, Full Professor of Corporate Finance, Wollgrasweg 49, 70599 Stuttgart, Germany
}

\section{A R T I C L E I N F O}

\section{Article history:}

Received 24 July 2015

Received in revised form 1 July 2016

Accepted 14 July 2016

Available online 21 July 2016

\section{JEL classification:}

G12

G24

G34

Keywords:

Special purpose acquisition company (SPAC)

Initial public offering (IPO)

Going public

Performance

\begin{abstract}
A B S T R A C T
Special purpose acquisition companies (SPACs) are cash shells that try to buy private operating firms to which they confer a public-listing status. Private operating firms tend to use SPACs as an alternative way to get listed, particularly in years with weak IPO activity and volatile markets, such as 2008 and 2009. In these two years, approximately $31 \%$ of firms went public through a SPAC acquisition rather than through an IPO. Our results from the analysis of 127 SPAC acquisitions and 1128 IPOs during the wave of "new-generation" SPACs starting in 2003 lend support to the conjecture that particular small and levered firms with low growth opportunities tend to use this vehicle. SPAC acquisitions also may be fueled by the cash-out motives of existing shareholders. Venture capitalists and private equity investors tend to refrain from using SPAC acquisitions as an exit route. Tracking long-term abnormal returns, we find that SPAC firms are associated with severe underperformance in comparison to the market, the industry and (comparable) IPO firms.
\end{abstract}

(c) 2016 Elsevier B.V. All rights reserved.

\section{Introduction}

The external capital that firms raise when they go public is of major interest to many growing businesses. Going public is also an important event for existing firm shareholders who may want to sell their holdings. Apart from the conventional method of initial public offerings (IPOs), firms may access public markets via a non-traditional route. The most popular non-traditional route is a reverse merger. As a result of this, private firms get listed not through their own IPO but because they are acquired by publicly listed natural- or cash-shell companies (Feldman, 2010). Natural shells are listed companies that have either gone bankrupt or sold a large part of their assets. In contrast, cash shells raise funds when they go public via a traditional IPO. Their sole intention is to acquire an operating firm, which obtains a public listing through this acquisition.

Before the recent financial crisis, a type of cash shell called a Special Purpose Acquisition Company (SPAC) became popular in the US (Cumming et al., 2014). 161 SPACs went public in the US between 2003 and 2008, raising a total of more than US\$22 billion in the course of their IPOs (Jenkinson and Sousa, 2011) and representing more than 13\% of all IPOs (see Fig. 1). In the peak year, 2007, 66 SPACs reached a public listing (almost 22\% of all IPOs). SPAC IPO activity dropped in 2009 and 2010, but has started to recover again since 2011. In 2015, we observed 20 SPAC IPOs (and 145 non-SPAC IPOs) in the US. SPACs, which are founded and managed by SPAC sponsors, are firms with "no or nominal operations and either no or nominal assets, assets consisting solely of cash and cash equivalents, or assets consisting of any amount of cash and cash equivalents and nominal

\footnotetext{
* Corresponding author.

E-mail addresses: johannes.kolb@uni-hohenheim.de (J. Kolb), tereza.tykvova@uni-hohenheim.de (T. Tykvová).
} 


\section{Number of non-SPAC IPOs, SPAC IPOs and SPAC acquisitions}

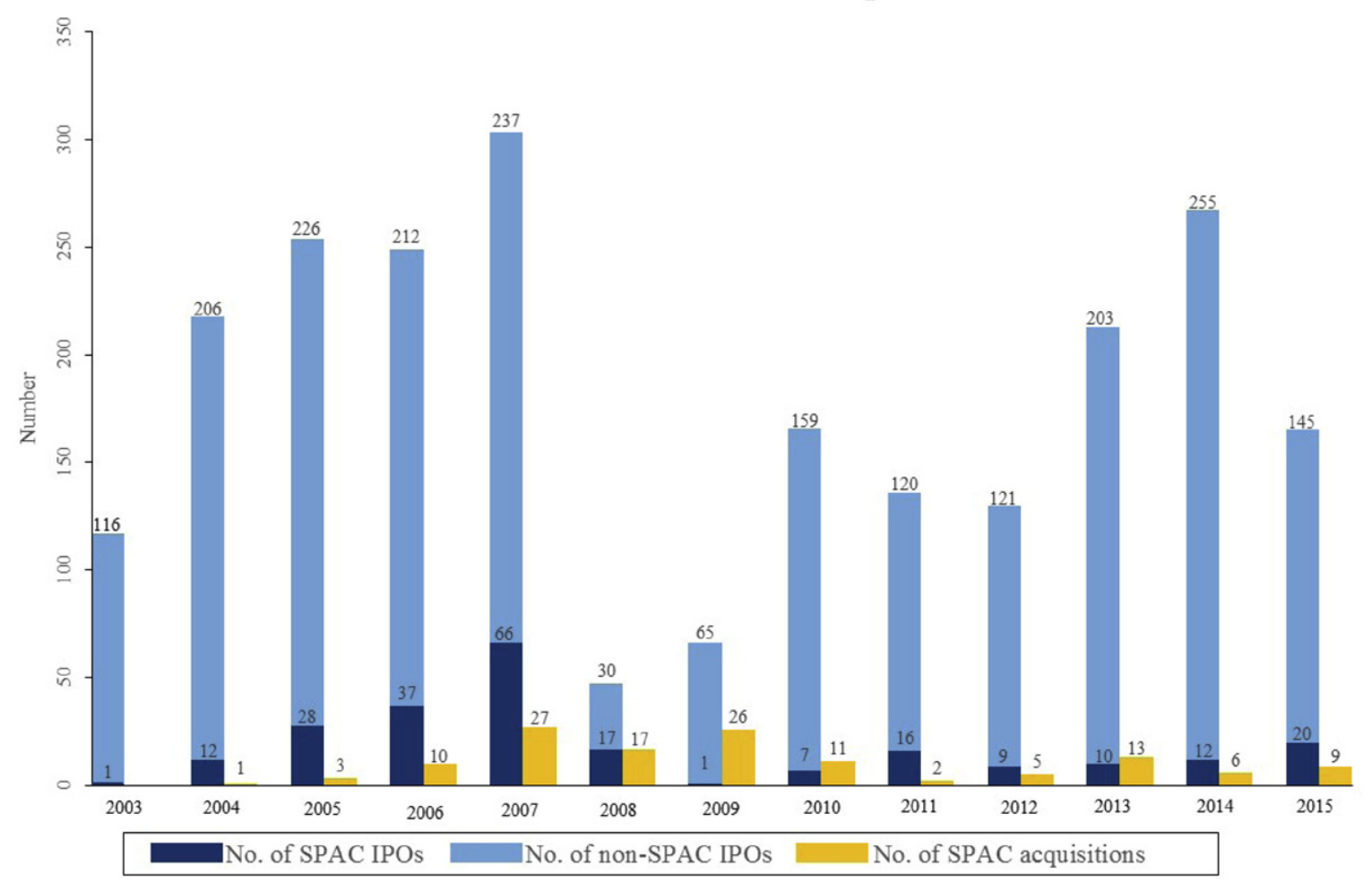

Source: Morgan Josef TriArtisan, EDGAR, Ellenoff Grossman \& Schole, Capital IQ

Fig. 1. Number of non-SPAC IPOs, SPAC IPOs and SPAC acquisitions. This figure presents the number of non-SPAC IPOs, SPAC IPOs and the number of SPAC acquisitions that were executed in the period 01/2003-12/2015. Source: Morgan Josef TriArtisan, EDGAR, Ellenoff Grossman \& Schole, Capital IQ.

other assets" (SEC, 2005). It is worth noting that they are the only form of shell companies that Ritter (2016) mentions in his latest IPO report. Within the sample period (2003-2015), we identify 236 SPAC IPOs with stronger SPAC IPO activity in bull than in bear markets.

In this paper, we examine private operating firms that SPACs acquire after their own IPO and compare them to IPO firms. We identify 130 such acquisitions within our sample period. The number of SPAC acquisitions is much lower than the number of SPAC IPOs because some SPACs fail in finding an appropriate target and some of the recently listed SPACs are still in the process of searching at the end of 2015. In 2008, the peak year of SPAC acquisition activity (relative to IPO activity), 36\% of firms went public via a SPAC acquisition rather than via an IPO. We focus on understanding why SPACs reach popularity among private firms that target a public listing as an alternative to traditional IPOs. We first investigate in what way market-, deal- and firm-specific variables are related to the route through which firms go public. Second, we analyze how firms that are acquired by SPACs ("SPAC firms" hereafter) and IPO firms perform in the long term.

For private firms that target a public listing, SPACs offer numerous advantages over IPOs. At the time that they confer the public listing status to a private firm, SPACs have money at their disposal. Therefore, it is likely that SPAC acquisitions will depend less on the current market environment than IPOs. The readily available liquidity may also provide existing SPAC firm shareholders the possibility of cashing out their holdings immediately at the SPAC acquisition. In addition, this route is expected to be relatively fast and cheap because SPAC firms do not have to undergo the lengthy and costly process of SEC registration; the SPAC vehicle has already gone through this process. Moreover, SPAC firms do not have to organize road shows and they usually face lower underpricing (Rodrigues and Stegemoller, 2014).

However, going public via a SPAC acquisition also has disadvantages for private firms. Although these firms do not have to convince a large group of investors (as it would be the case with an IPO), the shareholders of the SPAC vehicle have to approve the SPAC acquisition, which attaches uncertainty to SPAC acquisitions. Moreover, private firms' existing shareholders might fear a dilution of their holdings when using a SPAC acquisition due to the use of "in the money" warrants held by SPAC sponsors (Lakicevic et al., 2014). Investors might distrust SPACs and SPAC firms because they lack transparency (see, e.g., Cumming et al., 2014). As Arthur Levitt, a former SEC Chairman states, "I have never found any blank-check investment vehicle attractive. No matter what the reputation or what the sponsor might be. [...] They are the ultimate in terms of lack of transparency". ${ }^{\text {. }}$

1 http://www.investingdaily.com/10914/special-purpose-acquisition-companies-spacs-will-investors-live-long-and-prosper/. 
Our findings contribute to the emerging, but still limited, research on SPACs and their acquisitions. First, we add to the literature that addresses the drivers behind SPAC acquisitions. Recent research on SPACs, which helps to better understand the SPAC structure and its underlying mechanisms, is conducted by Cumming et al. (2014). ${ }^{2}$ They analyze factors which affect the shareholder approval probability of SPAC acquisitions. To the best of our knowledge, we are the first to consider the relation between the attractiveness of a SPAC acquisition (compared to an IPO) and the market environment as well as the cash-out opportunities of existing SPAC firm shareholders. We also examine further firm-specific variables, such as venture capital (VC) and private equity (PE) backing, ${ }^{3}$ which are not investigated in prior literature that addresses SPAC acquisitions vs. IPOs (e.g., Datar et al., 2012). Our results lend support to the conjecture that SPAC acquisitions tend to occur more often in volatile markets and that they offer existing SPAC firm shareholders the option to convert a larger fraction of their shares into cash immediately. Our findings furthermore indicate that SPACs provide smaller, more levered and low-growth firms, which may not succeed in IPOs, with the opportunity to enter public markets. These findings are robust towards alternative variable definitions, sample adjustments and towards matching.

Second, we enhance the literature on the performance of SPACs by analyzing the long-term performance of SPAC firms. We focus on the long-term wealth effects of up to 60 months following the SPAC acquisition, whereas prior SPAC research only analyzes SPAC acquisition announcement returns, SPAC acquisition completion returns or post-deal performance of SPACs for shorter time periods (Lewellen, 2009; Floros and Sapp, 2011; Jenkinson and Sousa, 2011; Datar et al., 2012; Lakicevic and Vulanovic, 2013; Rodrigues and Stegemoller, 2014). In addition, besides buy and hold abnormal returns, which are employed in prior literature, we use factor regressions to account for the exposure to risk factors and to address the cross-sectional dependence problem. The aim of these analyses is to discover whether SPAC sponsors are able to detect some hidden qualities in the firms they acquire that are not reflected in their financial characteristics at the time of the acquisition. We posit that if SPAC sponsors "kiss frogs" that "turn into princes," then SPAC firms should show a superior stock-market performance as soon as their qualities become visible to the market. Our results indicate that firms that go public via a SPAC acquisition are associated with severe long-term underperformance vis-à-vis the market, industry and firms of similar sizes and book-to-market ratios. Long-term underperformance is also documented for IPO firms in many studies, starting with the seminal paper by Ritter (1991) and including this study. However, we find that SPAC firms do significantly worse than IPO firms.

Third, we add to the existing SPAC literature by extending the investigation period and increasing the number of observations. While prior studies, such as Lewellen (2009); Floros and Sapp (2011); Jenkinson and Sousa (2011); Datar et al. (2012) and Cumming et al. (2014) mostly focus on the period between 2003 and 2010, we also add data from the period between 2011 and 2015. We complement our SPAC sample (we include 127 SPAC acquisitions in our main regression) with a sample of 1128 IPOs. Compared to that, Datar et al. (2012), the study that is most closely related to our investigations, employ only 35 SPAC acquisitions and 389 IPOs in their main analysis. Including more recent SPACs and their acquisitions is important because the SPAC market underwent substantial changes during our sample period (Lakicevic et al., 2014). Cumming et al. (2014) suggest that moves in market liquidity and investor needs during the financial crisis transformed the SPAC market. In addition, the "tender offer regulation" in 2009/2010 might influence the attractiveness of SPAC acquisitions relative to IPOs. The reform changes the structure of SPACs (see, e.g., Rodrigues and Stegemoller, 2011; Lakicevic et al., 2014) and may contribute to the resurrection of SPAC activity. Fig. 1 shows that there is only one SPAC IPO in 2009, but 74 SPAC IPOs between 2010 and 2015. Our results indicate that SPAC firms receive venture capital backing more often and that it takes less time to complete a public listing via a SPAC acquisition after the reform than before.

Fourth, we provide a contribution to the venture capital literature. We are not aware of any other study that considers SPAC acquisitions in the light of VC exits. VCs are repeated players in the IPO market, and the question arises whether VCs accept alternative vehicles and benefit from their potential advantages. On the one hand, SPAC acquisitions may offer VCs the possibility to convert a larger part of their holdings into cash immediately. On the other hand, VCs might want to increase their reputational capital in the new issue market and therefore would prefer the traditional IPO route. Additionally, VCs may serve as a credible signal of firm quality and thus reduce agency costs that arise in IPOs, making IPOs more likely. Our results suggest that VCs prefer IPOs to SPAC acquisitions and thus lend support to the latter argumentation.

The remainder of this paper is structured as follows: in Section 2, we discuss the literature on IPOs and SPACs as well as factors that may be related to the route through which firms go public. In Section 3, we present our data and descriptive statistics. In Section 4, we investigate in what way market-, deal- and firm-specific variables are related to the route that firms take in going public. In Section 5, we analyze the long-term performance of SPAC and IPO firms. We conclude in Section 6.

\section{IPOs versus SPACs}

The common method of going public for most firms is through an IPO, which involves selling new and existing shares. IPO activity is cyclical and depends on market conditions (Ritter, 1991). In the course of an IPO, existing shareholders usually realize only a partial exit, while a large fraction of their shares remains locked up (Brau et al., 2003). Indeed, Brav and Gompers (2003) report that most existing shareholders do not sell their holdings at the IPO. Firms that go public have to fulfill stringent legal requirements to become registered with the SEC. ${ }^{4}$ Furthermore, the IPO process involves various direct and indirect costs. The

\footnotetext{
2 Older studies in this area include Berger (2008) and Lakicevic and Vulanovic (2011).

${ }^{3}$ We thank an anonymous referee for making us aware of the importance of PE backing in firms acquired by SPACs.

4 Since April 2012, the JOBS Act has relaxed some requirements, making IPOs easier. We turn to this issue later.
} 
direct costs include an underwriting spread and other types of fees. The indirect costs arise from underpricing and from the fact that the top management has to spend time on marketing the IPO, organizing a roadshow, completing the book-building process and allocating the shares (Benveniste and Spindt, 1989; Ritter and Welch, 2002) at the expense of the daily operations and core activities of the business.

According to Gleason et al. (2005), reverse mergers, in which a publicly listed natural or cash shell acquires a private firm, are independent of market conditions and can be executed in both hot and cold IPO markets because the firms that are acquired by that method do not have to convince a large number of external investors. Aydogdu et al. (2007) note that reverse mergers may offer the firm they acquire a faster public listing at lower costs than an IPO would. Because shell companies are already listed on a stock exchange, their private targets obtain a public listing without having to go through the lengthy process of SEC registration. In addition, a reverse merger does not involve time-consuming procedures, such as marketing the shares, book-building or share allocation. For these reasons, shell companies and their private targets need to meet relatively low legal requirements and face lower costs. Gleason et al. (2005) note that the reverse merger fees equal only $2.7 \%$ of the transaction value on average, while Lee et al. (1996) find that the gross spreads for IPOs are 7.2\%. Furthermore, Gleason et al. (2008) note that underpricing is substantially lower for reverse mergers than for IPOs. Greene (2016), however, shows that the wealth of private firm owners is larger when they exit through an IPO instead of a reverse merger because firms which choose an IPO tend to have a higher growth potential.

This paper focuses on "new-generation" SPACs, which went public in the US in the period from 2003 until 2015, and their acquisitions. The first of these SPACs went public in August 2003 and performed its acquisition in August 2004. SPACs have several features that make them more transparent vehicles than natural-shell companies. While natural-shell companies typically arise from firms that are without assets or have gone bankrupt, SPACs are cash shell companies that are founded and equipped with funds for a single purpose: to acquire a private firm within a specified period. Moreover, SPACs undergo the listing process during their IPO. In addition to fulfilling the standard listing requirements for firms that go public, SPACs have to comply with additional regulations that were introduced after several cases of fraud involving shell vehicles during the 1980s. New-generation SPACs arose after the introduction of the Rule 419 Blank Check Offering Terms (Cumming et al., 2014), which aims to improve transparency, shareholder protection and the alignment of interests between shareholders and SPAC sponsors. Whereas in the 1980s SPACs were often classified as "penny stock" shell companies, all new-generation SPAC offerings are larger than US\$5 million, which exempts them from the penny stock rule (SEC Rule 3a-51-1).

We depict the SPAC structure in Fig. 2. To found a SPAC, the SPAC sponsors make a private placement for a nominal fee of US $\$ 25,000$ - the so-called sponsors' promote (Lakicevic et al., 2014). If an acquisition is successful, the sponsors' promote is worth approximately 20\% of the SPAC's equity (Cumming et al., 2014). In addition, the sponsors usually provide 3\% of the total SPAC funds to obtain warrants in exchange (Berger, 2008). Warrants carry the right to buy shares in the firm at a predetermined price after a successful acquisition. These warrants are, in general, "in the money." If the SPAC is liquidated, the sponsors lose their

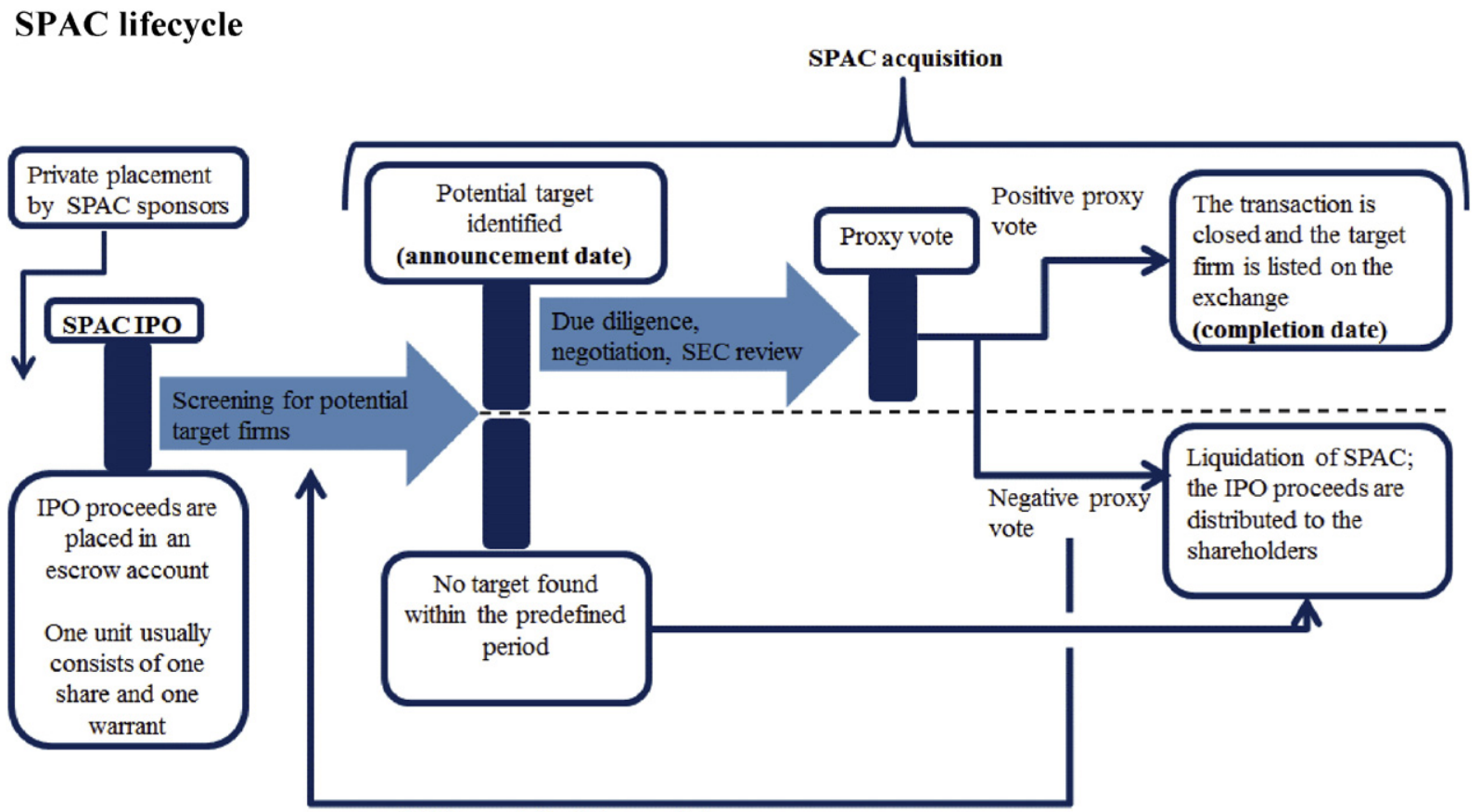

Within predefined time period

Fig. 2. SPAC lifecycle. This figure shows the structure and the lifecycle of a SPAC. 
invested funds (e.g., Jog and Sun, 2007). The reason for placing the sponsors' capital at risk is to strengthen their incentives to look for promising targets.

The private placement is followed by an IPO of the SPAC, during which it raises the majority of the funds that are necessary for a future acquisition. At the IPO, the SPAC typically issues units that can be traded and consist of public shares (common shares that carry voting rights) and warrants. At least $85 \%$ of the proceeds from a SPAC IPO must be placed in a trust account (which is invested in risk-free securities) and can only be released if the SPAC acquires a firm or is liquidated. According to Rodrigues and Stegemoller (2013), the proportion of the proceeds that is kept in the trust account increased from $85 \%$ in 2003 to $97 \%$ in 2010 and $100 \%$ in 2011.

Following the SPAC listing, the SPAC sponsors have a fixed amount of time, during which they do not obtain a salary or any other type of compensation, to find an appropriate acquisition target. The "screening for a target" period usually lasts between 18 and 24 months and is defined in the S-1 filing (Hale, 2007). Normally, SPACs focus on a specific region or industry in which the SPAC sponsors, who are often high-profile business persons with established networks, have a high degree of expertise (Lewellen, 2009). The expertise of the SPAC sponsors, that is an important SPAC asset, is disclosed in the SPAC IPO prospectus.

As soon as SPAC sponsors identify a potential target firm, they make an announcement to shareholders who own SPAC shares. In the period after the acquisition announcement date, SPAC sponsors perform an extensive due diligence, negotiate the structuring of the acquisition and wait for the SEC review of the disclosure documents relating to the SPAC acquisition. This process ends with the proxy vote in which the shareholders vote for or against the acquisition. A few days later, usually an $8 \mathrm{~K}$ filing is issued that confirms the SPAC acquisition. On this date, the public listing of the SPAC firm is completed. If the shareholders reject the acquisition, the SPAC sponsors have the right to look for another acquisition target. If the SPAC sponsors are not successful in acquiring a firm within the set time frame, the SPAC is liquidated and the proceeds and accrued interest from the trust account are distributed among the shareholders (Rodrigues and Stegemoller, 2013).

In the following, we discuss the market-, deal- and firm-specific variables that are likely to be relevant to the route through which firms go public.

\subsection{Market-specific variables}

The first market-specific variable we examine is market volatility. Previous research on IPOs shows that market timing is key to the successful execution of an IPO (Ritter, 1991) and that high volatility decreases its chances of success. For example, Schill (2004) finds that above-average market volatility reduces the frequency of IPOs by $13 \%$ and IPO proceeds by $21 \%$. We assume that SPAC acquisitions are less vulnerable to turbulent market conditions than IPOs because SPACs already possess liquidity at the time of the acquisition. Thus, in turbulent market environments, firms may increase their chances of becoming publicly listed by looking for an appropriate SPAC instead of aiming at an IPO.

The second market-specific variable that may be related to the route through which firms go public is cost of debt. As Lewellen (2009) observes, SPACs sometimes use not only the cash from the trust account but also raise debt to acquire firm shares. For that reason, he calls them "single-shot private equity funds" (see also Cumming et al., 2014). As long as SPACs raise debt to finance their acquisitions, one might expect that SPAC acquisitions are more frequent during periods characterized by cheap debt than during periods characterized by expensive debt because debt does not play a major role in IPOs.

\subsection{Deal specific variables}

Existing shareholders might see the going-public event as a chance to reduce their stake in the firm and to cash out some of their holdings (Barry et al., 1990). Liquidating holdings in IPOs often entails difficulties that are related to lock-up agreements and negative signaling (Bradley et al., 2001). Therefore, the existing shareholders usually only realize partial exits (Brau et al., 2003). By contrast, SPACs have cash available in the trust account, which they use to pay out the existing SPAC firm shareholders. We expect that, compared to IPOs, SPAC acquisitions offer the existing shareholders the option to convert a larger fraction of their shares into cash immediately in the course of the going-public event.

We conjecture that SPAC and IPO firms differ in time to resolution, i.e., the time they need to complete the transaction after its announcement date. For IPOs, we take the date of the going public announcement. For SPAC acquisitions, we use the date when the SPAC announces the prospective target to SPAC shareholders. We do not use the SPAC IPO date because we are not interested in measuring how long a SPAC needs to identify an appropriate target firm. Instead, we take the viewpoint of an operating firm that wants to go public. For this firm, the date that it matches with the SPAC is relevant. Floros and Sapp (2011) suggest that reverse mergers are executed faster than IPOs. However, traditional reverse mergers do not require a proxy vote as SPACs do, which may slow down the acquisition process. Moreover, SPAC acquisition documents are subject to SEC review. Therefore, it is unclear whether executing an IPO is more or less time-consuming than executing a SPAC acquisition. Interestingly, with the "tender offer regulation" many SPACs abandoned the proxy vote in favor of a tender offer. This structural change might reduce time to resolution for SPACs in recent years.

\subsection{Firm-specific variables}

The first two firm-specific variables we employ help to assess the question of whether low-quality firms use SPACs as a "back door" (e.g., Brown et al., 2013) to enter public markets. To capture the quality, we look at the current profitability and at growth 
opportunities. We use return on assets as a measure for current profitability. To proxy for growth opportunities, we employ Tobin's q, which we approximate with the market-to-book asset ratio, as suggested by Chung and Pruitt (1994). Chung and Pruitt (1994) show that their approximate Tobin's q, which requires only basic accounting information, is highly correlated to a Tobin's q calculated with a theoretically more exact technique. Given our data limitations, we stick to Chung and Pruitt (1994) measure in our analysis.

Our third firm-specific variable is debt ratio. On the one hand, highly levered firms may be too risky for IPO investors, so these firms may have to use the SPAC route. On the other hand, highly levered firms are unattractive for SPAC sponsors who want to use debt for the acquisition because this debt would further increase the firm's debt ratio. If the target firm already has a high debt level, additional debt could substantially increase the risk of bankruptcy and the cost of capital. This makes it difficult to predict how debt ratio is related to the likelihood of a firm choosing the SPAC route.

Fourth, we employ size. We expect that smaller firms prefer to employ SPAC acquisitions because, for these firms, it will be difficult to find a high-quality underwriter willing to manage the process of going public and to increase the chances of a successful listing (Fang, 2005). Even if such firms find an underwriter, the IPO will still be prohibitively costly due to the high (fixed) direct costs (Lee et al., 1996). Moreover, small firms may be too obscure and thus attract little interest from investors (Adjei et al., 2008).

Finally, we conjecture that VC involvement is also related to the route through which firms go public. IPOs are considered by VCs to be an important exit channel (Bascha and Walz, 2001; Bayar and Chemmanur, 2011). Due to the limited lifetime of their funds, VCs tend to be under pressure to cash out and realize returns quickly (Gompers, 1996; Giot and Schwienbacher, 2007). ${ }^{5}$ Because they want to avoid sending negative signals about the value of a portfolio firm to potential investors, VCs typically keep most of their holdings during an IPO and their shares remain locked for a specified period after the IPO (Gompers and Lerner, 2001). By contrast, due to readily available liquidity, SPAC acquisitions make it possible for VCs to cash out immediately. On these grounds, we would expect that VCs prefer SPAC acquisitions over IPOs. However, VCs may prefer using the IPO route over the SPAC route despite the cash out advantage that SPAC acquisitions offer for at least two reasons. The first reason might be VC reputation, which is a crucial factor in the business model of VCs (Megginson and Weiss, 1991). VCs might prefer to maintain or extend their reputation through successful IPOs (Nahata, 2008) over cashing out. The second reason might be VC ability to signal. If VCs are able to send creditable signals, they can effectively reduce information asymmetries between an IPO firm and new investors and thus decrease costs and increase the likelihood of a successful IPO (Megginson and Weiss, 1991). We expect that similar arguments hold for PE involvement because PEs also are under pressure for fast cash outs, are repeated players and profit from a good reputation. As PEs do not tend to exit via IPOs as often as VCs (Phalippou and Gottschalg, 2009), we expect the PE effect to be weaker than the VC effect.

\section{Sample and descriptive statistics}

\subsection{SPAC and IPO sample}

We gather our data on SPAC IPOs and SPAC acquisitions during the new-generation SPAC wave from the report issued by Morgan Joseph TriArtisan (SPAC market update March 2014), ${ }^{6}$ from the Electronic Data Gathering and Retrieval (EDGAR) database maintained by the US Securities and Exchange Commission, from press statements issued by Ellenoff Grossman \& Schole LLP and from Capital IQ. Between 2003 and 2015, we identify 236 SPAC IPOs and 130 SPAC acquisitions in the US. The first recorded SPAC IPO, which started this wave, is that of the Millstream Acquisition Corporation in August 2003. The first SPAC acquisition-in which Millstream Acquisition Corporation acquired NationsHealth Inc.-took place in August 2004. Our final sample, which we restrict to firms for which deal- and firm-specific variables are available, contains 127 SPAC firms. Although all SPACs are traded in the US, they acquired firms incorporated worldwide.

To retrieve the control sample of non-SPAC IPOs, we use Capital IQ. A query for all public offerings on US exchanges that are closed, effective or successful and larger than US\$5 million in the sample period yields 3149 IPO firms. Because we want to compare SPAC acquisitions of operating firms with IPOs of operating firms, we exclude shell companies, carve-outs, demutualizations, direct listings, mutual funds, bank conversions, best-effort basis agreements, unit offerings and offerings including warrants from the control sample. As in the case of SPAC firms, it does not matter whether some of the IPO firms in the control sample are incorporated in other countries; however, we do not consider firms that are incorporated in continents where no SPAC firms exist. We also exclude IPO firms from industries in which no SPAC acquisitions occur. Having filtered the original IPO sample and only kept IPOs for which we have deal- and firm-specific variables, we are left with a final control sample of 1128 IPO firms.

Fig. 1 indicates that after the first SPAC acquisition in August 2004, the number of SPAC IPOs and SPAC acquisitions increased dramatically. In the peak year, 2007, SPAC IPOs accounted for approximately $22 \%$ of all US IPOs. These SPACs led to increased acquisition activity in subsequent years with SPACs becoming very popular as a vehicle for going public between 2007 and 2009. When we compare the SPAC acquisitions to the number of IPOs, we find a peak year in 2008 . In this year, $36 \%$ of firms went public through this route. A year later, the share of SPAC acquisitions remained high at almost 29\%, while only one SPAC went public.

\footnotetext{
5 The pressure to cash out, to which VCs are exposed, is not the same across all portfolio firms, but will depend, for example, on the length of the holding period or the number of financing rounds. In our investigations, however, we capture the average effect and do not distinguish for the heterogeneity within the subsample of VCbacked firms.

${ }^{6}$ http://mjta.com/i/SPAC_Monthly.pdf.
} 
The SPAC IPOs started to recover in 2011. In 2015, we register 20 SPAC IPOs and 9 SPAC acquisitions compared to 145 non-SPAC IPOs.

Table 1 shows the composition of our sample of SPAC firms and IPO firms in different regions and industries. Although all SPACs are traded in the US, they acquire firms incorporated worldwide. Of the 127 SPAC firms, 83\% are located in North America (of which $96 \%$ are located in the US), 13\% in Asia and 4\% in Europe. Similarly, $82 \%$ of all IPO firms are incorporated in North America (of which 99\% are located in the US), 12\% in Asia and 5\% in Europe. Moreover, based on 2-digit SIC codes, 30\% of all SPAC firms operate in the manufacturing industry, $24 \%$ in the services industry and $16 \%$ in the transportation and utilities industries. Manufacturing firms account for 33\% of IPO firms in our sample, while $27 \%$ are involved in the service industry and $17 \%$ belong to the finance, insurance and real estate industries.

\subsection{Market-, deal- and firm-specific variables}

We complement our data on IPOs and SPAC acquisitions with market-, deal- and firm-specific variables drawn primarily from Capital IQ Compustat US and SDC Platinum. We obtain additional data from the EDGAR database and from the websites of individual firms. Table 2 presents the definitions of variables we use in the main regression and the sources from which we derive them.

Table 3 presents summary statistics for our variables. To see if there are any differences between the characteristics of SPAC acquisitions and IPOs, we run Wilcoxon-Mann-Whitney tests and $t$-tests. With respect to the market specific variables, we note that in turbulent market environments firms tend to use SPAC acquisitions rather than IPOs to go public. The variance of the S\&P 500 total return index during the six months preceding the deal announcement, which serves as a proxy for market volatility, is significantly higher for SPAC acquisitions than for IPOs at the $1 \%$ level. In non-tabulated results, we find a positive correlation between the monthly number of SPAC IPOs and the lagged market return, suggesting that investors are willing to provide their money to these vehicles in bull rather than bear markets. Cost of debt does not seem to be related to the route through which firms go public.

While looking at deal-specific variables, we observe that, in general, the existing firm shareholders realize a larger cash out ratio through SPAC acquisitions than through IPOs. The difference is significant at the 1\% level. Generally, SPAC acquisitions take an average of 6.7 months from the announcement of the potential target firm to the completion of the SPAC acquisition, while the time to resolution from the going-public announcement to IPO completion amounts to only 3.9 months. This difference is significant at the $1 \%$ level.

The first firm-specific variable is return on assets: the mean SPAC firm return on assets equals $1.4 \%$ and the mean IPO firm return on assets equals 3.2\% on average. However, only the Wilcoxon-Mann-Whitney test is significant at the $1 \%$ level. Growth opportunities of SPAC firms seems to be lower than those of IPO firms; in our sample the mean market to book asset ratio for SPAC firms equals 1.8 while for IPO firms it is 3.3. The difference is significant at the $1 \%$ level. At $60.7 \%$, the debt ratio is significantly higher for SPAC firms compared to $46.6 \%$ for IPO firms at end of the quarter after the effective date. Both the Wilcoxon-Mann-Whitney test and the t-test are significant at the $1 \%$ level. As expected, SPAC firms are substantially smaller: the mean size (measured as total assets) amounts to US\$334.9 million, compared to US\$923.1 million in the case of IPO firms. This difference is also significant at the 1\% level. When we examine VC involvement, we find that VCs have stakes in $33.1 \%$ of all IPO firms but only in $14.2 \%$ of all SPAC firms. This difference is highly significant at the $1 \%$ level, suggesting that when VCs take their portfolio firms public they prefer the traditional IPO route to the SPAC route. In line with our expectations, PE involvement seems to be less important than venture capital backing in our sample. $12.6 \%$ of SPACs are backed by PEs, whereas $20.8 \%$ of IPOs obtain private equity.

Table 4 shows pairwise correlation coefficients between each pair of variables that we use in the main analysis. The highest correlation of $-40 \%$ is between the variables market volatility and cost of debt, so multicollinearity should not destroy our

Table 1

Sample overview.

\begin{tabular}{|c|c|c|c|c|c|c|c|}
\hline \multirow[t]{2}{*}{ Category } & \multirow[t]{2}{*}{ Subcategory } & \multicolumn{2}{|c|}{ SPAC acquisitions } & \multicolumn{2}{|l|}{ IPOs } & \multicolumn{2}{|l|}{ Total } \\
\hline & & Frequency & Percent & Frequency & Percent & Frequency & Percent \\
\hline \multirow[t]{5}{*}{ Regions (no. of transactions) } & North America & 105 & 82.68 & 923 & 81.83 & 1028 & 81.91 \\
\hline & Europe & 5 & 3.94 & 58 & 5.14 & 63 & 5.02 \\
\hline & Asia & 16 & 12.60 & 132 & 11.70 & 148 & 11.79 \\
\hline & Latin America/Caribbean & 1 & 0.79 & 15 & 1.33 & 16 & 1.27 \\
\hline & Total & 127 & & 1128 & & 1255 & \\
\hline \multirow[t]{7}{*}{ Industries (no. of transactions) } & Manufacturing & 38 & 29.92 & 371 & 32.89 & 409 & 32.59 \\
\hline & Transportation \& Public Utilities & 20 & 15.75 & 86 & 7.62 & 106 & 8.45 \\
\hline & Retail Trade & 9 & 7.09 & 69 & 6.12 & 78 & 6.22 \\
\hline & Finance, Insurance, Real Estate & 13 & 10.24 & 194 & 17.20 & 207 & 16.49 \\
\hline & Services & 30 & 23.62 & 305 & 27.04 & 335 & 26.69 \\
\hline & Other & 17 & 13.39 & 103 & 9.13 & 120 & 9.56 \\
\hline & Total & 127 & & 1128 & & 1255 & \\
\hline
\end{tabular}

This table provides information on the sample composition of SPAC acquisitions and IPOs executed in the period 01/2004-12/2015 by region and industry. 
Table 2

Variable definitions and sources.

\begin{tabular}{|c|c|c|c|}
\hline Variable name & Unit & Definition & Source \\
\hline \multicolumn{4}{|l|}{ Market specific variables } \\
\hline Market volatility & Thousand US\$ & $\begin{array}{l}\text { Average lagged six-month variance on S\&P } 500 \text { index on the } \\
\text { announcement date*. }\end{array}$ & Capital IQ \\
\hline Cost of debt & $\%$ & 10 year T-bill rate on the announcement date*. & Federal Reserve Bank of St. Louis (FRED) \\
\hline \multicolumn{4}{|l|}{ Deal specific variables } \\
\hline Cash out & $\%$ & $\begin{array}{l}\text { Cash as the percentage of the total SPAC acquisition value; IPO } \\
\text { proceeds that went to existing shareholders as percentage of } \\
\text { the market equity value. }\end{array}$ & SDC Platinum, Capital IQ, EDGAR \\
\hline Time to resolution & Months & $\begin{array}{l}\text { Time period from the announcement date }{ }^{*} \text { to the completion } \\
\text { date (for SPACs) or to the pricing date (for IPOs). }\end{array}$ & Capital IQ, EDGAR, firm websites \\
\hline \multicolumn{4}{|c|}{ Firm specific variables (end of quarter after the completion date) } \\
\hline Return on assets & $\%$ & EBIT divided by total assets (quarter values). & Compustat US, Capital IQ \\
\hline Market to book asset ratio & Ratio & $\begin{array}{l}\text { Market value of equity plus book value of total liabilities } \\
\text { divided by the book value of equity and book value of total } \\
\text { liabilities (quarter values). }\end{array}$ & Compustat US, SDC Platinum, Capital IQ \\
\hline Debt ratio & $\%$ & $\begin{array}{l}\text { Total liabilities divided by total assets. Total liabilities contain } \\
\text { accounts payable, accrued expenses, short-term borrowings, } \\
\text { current portion of long-term debt, long-term debt, minority } \\
\text { interest and other liabilities (quarter values). }\end{array}$ & Compustat US, Capital IQ \\
\hline Size & Million US\$ & Total assets (quarter values). & Compustat US, Capital IQ \\
\hline VC involvement & Dummy & $\begin{array}{l}\text { The variable equals } 1 \text { if a VC is involved and } 0 \text { otherwise on } \\
\text { the completion date. }\end{array}$ & Capital IQ, EDGAR, Thomson One Private Equity \\
\hline PE involvement & Dummy & $\begin{array}{l}\text { The variable equals } 1 \text { if a private equity fund is involved and } 0 \\
\text { otherwise on the completion date. }\end{array}$ & Capital IQ, EDGAR, Thomson One Private Equity \\
\hline
\end{tabular}

In this table we define the market-, deal- and firm-specific variables we use and provide the sources from which we derive these variables.

* for SPACS: the date when the SPAC sponsors announce a potential private target to their shareholders; for IPOs: the date of the going public announcement.

Table 3

Summary statistics for SPAC acquisitions and IPOs.

\begin{tabular}{|c|c|c|c|c|c|c|c|c|c|c|c|c|c|c|}
\hline \multirow[b]{2}{*}{ Variable } & \multicolumn{4}{|c|}{ Full sample } & \multicolumn{4}{|c|}{ SPAC acquisitions/SPAC firms } & \multicolumn{4}{|c|}{ IPOs/IPO firms } & \multirow{2}{*}{$\frac{\text { WMW Test }}{\text { Value }}$} & \multirow{2}{*}{$\frac{t \text {-Test }}{\text { Value }}$} \\
\hline & Median & Mean & Stdev & $N$ & Median & Mean & Stdev & $N$ & Median & Mean & Stdev & $N$ & & \\
\hline \multicolumn{15}{|l|}{ Market specific variables } \\
\hline Market volatility & 5.33 & 6.86 & 7.72 & 1255 & 6.06 & 10.37 & 14.98 & 127 & 5.26 & 6.47 & 6.31 & 1128 & $2.66^{* * *}$ & $2.90^{* * * *}$ \\
\hline Cost of debt & 3.83 & 3.63 & 1.01 & 1255 & 3.83 & 3.68 & 1.07 & 127 & 3.82 & 3.62 & 1.00 & 1128 & 0.81 & 0.58 \\
\hline \multicolumn{15}{|l|}{ Deal specific variables } \\
\hline Cash out & 1.48 & 7.97 & 15.89 & 1255 & 15.11 & 29.96 & 34.43 & 127 & 1.26 & 5.50 & 9.37 & 1128 & $5.54^{* * *}$ & $7.98^{* * *}$ \\
\hline Time to resolution & 3.30 & 4.21 & 3.50 & 1255 & 6.13 & 6.65 & 3.79 & 127 & 3.17 & 3.94 & 3.35 & 1128 & $9.03^{* * *}$ & $7.72^{* * *}$ \\
\hline \multicolumn{15}{|c|}{ Firm specific variables (end of quarter after the effective date) } \\
\hline Return on assets & 6.40 & 2.99 & 24.79 & 1255 & 2.74 & 1.40 & 23.12 & 127 & 6.71 & 3.17 & 24.98 & 1128 & $-2.44^{* * *}$ & -0.81 \\
\hline Market to book asset ratio & 2.20 & 3.16 & 2.85 & 1255 & 1.21 & 1.76 & 1.75 & 127 & 2.36 & 3.31 & 2.91 & 1128 & $-9.30^{* * *}$ & $-8.76^{* * *}$ \\
\hline Debt ratio & 42.27 & 48.05 & 31.85 & 1255 & 58.93 & 60.68 & 30.90 & 127 & 40.84 & 46.63 & 31.65 & 1128 & $4.87^{* * *}$ & $4.85^{* * *}$ \\
\hline Size & 230.56 & 863.54 & 1857.06 & 1255 & 143.94 & 334.86 & 941.21 & 127 & 242.68 & 923.06 & 1924.37 & 1128 & $-4.65^{* * *}$ & $-5.81^{* * *}$ \\
\hline VC involvement & 0.00 & 0.31 & - & 1255 & 0.00 & 0.14 & - & 127 & 0.00 & 0.33 & - & 1128 & $-4.36^{* * *}$ & $-5.54^{* * *}$ \\
\hline PE involvement & 0.00 & 0.20 & - & 1255 & 0.00 & 0.13 & - & 127 & 0.00 & 0.21 & - & 1128 & $-2.20^{* *}$ & $-2.58^{* *}$ \\
\hline
\end{tabular}

This table presents sample summary statistics, the values of the Wilcoxon-Mann-Whitney (WMW) test and $t$-test that we run to compare the market-, deal- and firm-specific variables between SPAC acquisitions and IPOs executed in the period 01/2004-12/2015. All variables are defined in Table 2. We Winsorize all dealand firm-specific variables at the $2 \%$ level. ${ }^{*},{ }^{* *}$, and ${ }^{* * *}$ indicate statistical significance at the $10 \%, 5 \%$ and $1 \%$ levels, respectively.

multivariate tests. In this context, it might be interesting to note that if we excluded market volatility from our multivariate regressions, the results would not change much.

\section{Likelihood of a SPAC acquisition}

\subsection{The model and its specifications}

To model the likelihood of a SPAC acquisition, we employ a logistic regression model with the dependent variable $P(S P A C)_{i}$, which is binary and equals 1 for SPAC firms and 0 for IPO firms.7

\footnotetext{
7 Most existing studies use a maximum likelihood estimator and a simple binary regression model for similar problem settings. To measure the relative attractiveness of IPOs in comparison to mergers and sellouts, Brau et al. (2003) and Poulsen and Stegemoller (2008) use a logistic regression model. Brown et al. (2013) employ a probit model and Adjei et al. (2008) a logistic model to distinguish between firms that decide to go public via an IPO and firms that choose a reverse merger.
} 
Table 4

Correlation matrix.

\begin{tabular}{|c|c|c|c|c|c|c|c|c|c|c|}
\hline & $\begin{array}{l}\text { Market } \\
\text { volatility }\end{array}$ & $\begin{array}{l}\text { Cost of } \\
\text { debt }\end{array}$ & Cash out & $\begin{array}{l}\text { Time to } \\
\text { resolution }\end{array}$ & $\begin{array}{l}\text { Return on } \\
\text { assets }\end{array}$ & $\begin{array}{l}\text { Market to book } \\
\text { asset ratio }\end{array}$ & $\begin{array}{l}\text { Debt } \\
\text { ratio }\end{array}$ & $\log ($ size $)$ & $\begin{array}{l}\text { VC } \\
\text { involvement }\end{array}$ & $\begin{array}{l}\mathrm{PE} \\
\text { involvement }\end{array}$ \\
\hline Market volatility & 1.00 & & & & & & & & & \\
\hline Cost of debt & $-0.40^{* * *}$ & 1.00 & & & & & & & & \\
\hline Cash out & -0.02 & $0.10^{* * *}$ & 1.00 & & & & & & & \\
\hline Time to resolution & 0.01 & $0.14^{* * *}$ & $0.12^{* * *}$ & 1.00 & & & & & & \\
\hline Return on assets & -0.01 & $0.14^{* * * *}$ & $0.14^{* * *}$ & -0.02 & 1.00 & & & & & \\
\hline $\begin{array}{l}\text { Market to book } \\
\text { asset ratio }\end{array}$ & -0.01 & $-0.05^{*}$ & $-0.15^{* * *}$ & $-0.13^{* * *}$ & 0.01 & 1.00 & & & & \\
\hline Debt ratio & 0.02 & $-0.05^{*}$ & $0.15^{* * * *}$ & $0.15^{* * *}$ & $0.14^{* * *}$ & -0.01 & 1.00 & & & \\
\hline $\log ($ size $)$ & 0.03 & $-0.07^{* *}$ & $0.07^{* *}$ & 0.01 & $0.27^{* * *}$ & $-0.37^{* * *}$ & $0.33^{* * *}$ & 1.00 & & \\
\hline VC involvement & -0.00 & $0.08^{* * *}$ & 0.00 & 0.00 & -0.03 & 0.00 & -0.03 & $0.10^{* * *}$ & 1.00 & \\
\hline PE involvement & $-0.06^{* *}$ & $0.07^{* * *}$ & $0.08^{* * * *}$ & $0.06^{* *}$ & $0.20^{* * *}$ & $-0.09^{* * *}$ & $0.28^{* * *}$ & $0.26^{* * *}$ & $0.06^{*}$ & 1.00 \\
\hline
\end{tabular}

This table presents a pairwise correlation matrix of the variables that we use in the analysis of the SPAC acquisitions and IPOs that were executed in the period 01/ 2004-12/2015.

All variables are defined in Table 2 . We winsorize all deal- and firm-specific variables at the $2 \%$ level. *, **, and *** indicate statistical significance at the $10 \%, 5 \%$ and $1 \%$ levels, respectively.

The main specification is:

$P(\text { SPAC })_{i}=1 /\left(1+e^{\wedge}\left(\alpha+\beta_{1}\right.\right.$ Market volatility $_{i}+\beta_{2}$ Cost of debt d $_{i}+$

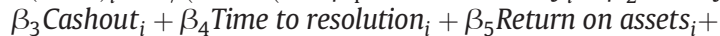

$\beta_{6}$ Market to book asset ratio $+\beta_{7}$ Debt ratio ${ }_{i}+\beta_{8} \log (\text { size })_{i}+$

$\beta_{9}$ VC involvement ${ }_{i}+\beta_{10}$ PE involvement in $_{i}+\sum_{j=11}^{21} \beta_{j}$ Year fixed effects $_{i, j}+$

$\sum_{k=22}^{24} \beta_{k}$ Region fixed effects $s_{i, k}+\sum_{l=25}^{27} \beta_{l}$ Industry fixed effects $\left.s_{i, l}+u_{i}\right)$ ),

where individual firms are indexed by $i$. We present the definitions of all variables of interest in Table 2 . In addition, we use year fixed effects, which capture the year in which the deal is executed, to control for any unobservable time-specific developments that may be related to some of the regressors and to the route through which firms go public. We also include region fixed effects to control for potential unobservable differences in market-, deal- and firm-specific variables due to regional factors that may affect the method of going public. To generate these variables, we aggregate SPAC firms and IPO firms on the basis of four different world regions, namely, Asia, Europe, North America and Latin America (Caribbean). Finally, industry fixed effects reflect potential differences across industries that may be related to the route through which firms go public. We include fixed effects for the three largest industries (i) manufacturing, (ii) services and (iii) finance, insurance and real estate. The remaining industry classifications represent the reference category.

\subsection{Main results}

In Table 5, we present the average marginal effects and their standard errors, which we cluster by year and country to adjust for possible correlations within the clusters. We present our main results in Specification 1. Examining the market specific variables, we note that in turbulent market environments firms tend to prefer SPAC acquisitions to IPOs. The variable market volatility is positive and significant at the $5 \%$ level, which suggests that, compared to SPAC acquisitions, it may be more difficult to access the public market through IPOs when market conditions are harsh. With a one-standard-deviation increase in market volatility, the probability of going public through a SPAC acquisition increases by 0.77 percentage points. In contrast to the univariate test, the regression analysis indicates that the variable cost of debt matters. More expensive debt is associated with a lower likelihood of SPAC acquisitions (significant at the 5\% level), which supports the view that SPAC firms consider current debt terms when they choose a way to access the public market.

The first deal specific variable, cash out, is significantly higher (at the $1 \%$ level) when firms use SPAC acquisitions. This suggests that the existing firm shareholders who want to cash out some of their holdings can do this more easily through SPAC acquisitions. The variable time to resolution is positive and significant (at the $1 \%$ level), which indicates that SPAC acquisitions take longer to be executed than IPOs. We suppose that this is because proxy voting causes substantial delays in the process of acquiring a firm. Both of these deal-specific variables are also economically important: with a one-standard-deviation increase in cash out and time to resolution, the probability of going public through a SPAC acquisition increases by 4.04 percentage points and 2.38 percentage points, respectively.

Firm-specific variables show, in line with prior studies (e.g., Datar et al., 2012), that SPAC firms tend to be firms of lower quality. Return on assets, which reflects the current profitability, is negative but insignificant. The variable market-to-book asset ratio has a negative sign, which supports the view that SPAC firms are associated with relatively weak growth opportunities. The positive marginal effect of the debt ratio variable suggests that more levered firms are more likely to use the SPAC route than the IPO route. Additionally, in line with our expectations, the size of SPAC firms is smaller than that of firms involved in 
Table 5

Likelihood of a SPAC acquisition.

\begin{tabular}{|c|c|c|c|c|c|c|c|}
\hline & $(1)$ & $(2)$ & (3) & $(4)$ & $(5)$ & (6) & (7) \\
\hline & Main specification & Announcement date & Expected ratios & $\begin{array}{l}\text { Matching (size, } \\
\text { industry, age) }\end{array}$ & Regulation VC & Regulation PE & Regulation time \\
\hline Market volatility & $\begin{array}{l}0.0010^{* *} \\
(0.0005)\end{array}$ & $\begin{array}{l}0.0013^{* *} \\
(0.0006)\end{array}$ & $\begin{array}{l}0.0027^{* * *} \\
(0.0010)\end{array}$ & $\begin{array}{l}0.0094^{*} \\
(0.0055)\end{array}$ & $\begin{array}{l}0.0013^{*} \\
(0.0007)\end{array}$ & $\begin{array}{l}0.0013^{*} \\
(0.0007)\end{array}$ & $\begin{array}{l}0.0015^{* * *} \\
(0.0006)\end{array}$ \\
\hline Cost of debt & $\begin{array}{l}-0.0305^{* *} \\
(0.0124)\end{array}$ & $\begin{array}{l}-0.0463^{* * *} \\
(0.0139)\end{array}$ & $\begin{array}{l}-0.0177 \\
(0.0127)\end{array}$ & $\begin{array}{l}-0.1154^{*} \\
(0.0639)\end{array}$ & $\begin{array}{l}-0.0616^{* * *} \\
(0.0174)\end{array}$ & $\begin{array}{l}-0.0612^{* * *} \\
(0.0174)\end{array}$ & $\begin{array}{l}-0.0572^{* * *} \\
(0.0177)\end{array}$ \\
\hline Cash out & $\begin{array}{l}0.2543^{* * *} \\
(0.0204)\end{array}$ & $\begin{array}{l}0.2760^{* * *} \\
(0.0171)\end{array}$ & & $\begin{array}{l}0.7121^{* * *} \\
(0.1438)\end{array}$ & $\begin{array}{l}0.2601^{* * *} \\
(0.0265)\end{array}$ & $\begin{array}{l}0.2602^{* * *} \\
(0.0263)\end{array}$ & $\begin{array}{l}0.2545^{* * *} \\
(0.0258)\end{array}$ \\
\hline Time to resolution & $\begin{array}{l}0.0068^{* * *} \\
(0.0025)\end{array}$ & $\begin{array}{l}0.0079^{* * *} \\
(0.0027)\end{array}$ & & $\begin{array}{l}0.0105^{* *} \\
(0.0051)\end{array}$ & $\begin{array}{l}0.0083^{* * *} \\
(0.0022)\end{array}$ & $\begin{array}{l}0.0083^{* * *} \\
(0.0022)\end{array}$ & $\begin{array}{l}0.0104^{* * *} \\
(0.0030)\end{array}$ \\
\hline Return on assets & $\begin{array}{l}-0.0071 \\
(0.0188)\end{array}$ & $\begin{array}{l}0.0125 \\
(0.0175)\end{array}$ & $\begin{array}{l}0.0307 \\
(0.0208)\end{array}$ & $\begin{array}{l}-0.2107^{* *} \\
(0.0830)\end{array}$ & $\begin{array}{l}-0.0214 \\
(0.0178)\end{array}$ & $\begin{array}{l}-0.0203 \\
(0.0188)\end{array}$ & $\begin{array}{l}-0.0239 \\
(0.0210)\end{array}$ \\
\hline Market to book asset ratio & $\begin{array}{l}-0.0328^{* * *} \\
(0.0089)\end{array}$ & $\begin{array}{l}-0.0059^{* *} \\
(0.0024)\end{array}$ & $\begin{array}{l}-0.0719^{* * *} \\
(0.0143)\end{array}$ & $\begin{array}{l}-0.0369^{* * *} \\
(0.0102)\end{array}$ & $\begin{array}{l}-0.0328^{* * *} \\
(0.0097)\end{array}$ & $\begin{array}{l}-0.0329^{* * *} \\
(0.0099)\end{array}$ & $\begin{array}{l}-0.0319^{* * *} \\
(0.0096)\end{array}$ \\
\hline Debt ratio & $\begin{array}{l}0.1371^{* * *} \\
(0.0221)\end{array}$ & $\begin{array}{l}0.0277^{* *} \\
(0.0115)\end{array}$ & $\begin{array}{l}0.2219^{* * *} \\
(0.0306)\end{array}$ & $\begin{array}{l}0.3978^{* * *} \\
(0.0679)\end{array}$ & $\begin{array}{l}0.1276^{* * *} \\
(0.0228)\end{array}$ & $\begin{array}{l}0.1283^{* * *} \\
(0.0233)\end{array}$ & $\begin{array}{l}0.1305^{* * *} \\
(0.0235)\end{array}$ \\
\hline $\log ($ size $)$ & $\begin{array}{l}-0.0528^{* * *} \\
(0.0085)\end{array}$ & $\begin{array}{l}-0.0351^{* * *} \\
(0.0070)\end{array}$ & $\begin{array}{l}-0.0703^{* * *} \\
(0.0094)\end{array}$ & & $\begin{array}{l}-0.0491^{* * *} \\
(0.0094)\end{array}$ & $\begin{array}{l}-0.0492^{* * *} \\
(0.0094)\end{array}$ & $\begin{array}{l}-0.0478^{* * * *} \\
(0.0097)\end{array}$ \\
\hline VC involvement & $\begin{array}{l}-0.0438^{* * *} \\
(0.0137)\end{array}$ & $\begin{array}{l}-0.0680^{* * *} \\
(0.0174)\end{array}$ & $\begin{array}{l}-0.0367^{* *} \\
(0.0179)\end{array}$ & $\begin{array}{l}-0.1492^{* * *} \\
(0.0513)\end{array}$ & $\begin{array}{l}-0.0537^{* * *} \\
(0.0167)\end{array}$ & $\begin{array}{l}-0.0505^{* * *} \\
(0.0154)\end{array}$ & $\begin{array}{l}-0.0505^{* * *} \\
(0.0166)\end{array}$ \\
\hline PE involvement & $\begin{array}{l}-0.0364^{*} \\
(0.0207)\end{array}$ & $\begin{array}{l}-0.0049 \\
(0.0240)\end{array}$ & $\begin{array}{l}-0.0518^{* * *} \\
(0.0186)\end{array}$ & $\begin{array}{l}-0.1766^{* * *} \\
(0.0612)\end{array}$ & $\begin{array}{l}-0.0304^{*} \\
(0.0177)\end{array}$ & $\begin{array}{l}-0.0271^{*} \\
(0.0157)\end{array}$ & $\begin{array}{l}-0.0281^{*} \\
(0.0170)\end{array}$ \\
\hline Exp. diff. cash out & & & $\begin{array}{l}1.2154^{* * *} \\
(0.3058)\end{array}$ & & & & \\
\hline Exp. diff. time to resol. & & & $\begin{array}{l}0.0141^{*} \\
(0.0081)\end{array}$ & & & & \\
\hline Regulation & & & & & $\begin{array}{l}-0.1388^{* * *} \\
(0.0427)\end{array}$ & $\begin{array}{l}-0.1346^{* * *} \\
(0.0427)\end{array}$ & $\begin{array}{l}-0.0883^{*} \\
(0.0528)\end{array}$ \\
\hline VC involvement $*$ regulation & & & & & $\begin{array}{l}0.0748^{*} \\
(0.0547)\end{array}$ & & \\
\hline PE involvement $*$ regulation & & & & & & $\begin{array}{l}0.0304 \\
(0.0438)\end{array}$ & \\
\hline Time to resolution $*$ regulation & & & & & & & $\begin{array}{l}-0.0179^{*} \\
(0.01053)\end{array}$ \\
\hline Year fixed effects & Yes & Yes & No & Yes & No & No & No \\
\hline Region fixed effects & Yes & Yes & Yes & Yes & Yes & Yes & Yes \\
\hline Industry fixed effects & Yes & Yes & Yes & No & Yes & Yes & Yes \\
\hline$N$ & 1255 & 1125 & 1131 & 254 & 1255 & 1255 & 1255 \\
\hline$N$ (SPAC acquisitions) & 127 & 103 & 126 & 127 & 127 & 127 & 127 \\
\hline$N$ (IPOs) & 1128 & 1022 & 1005 & 127 & 1128 & 1128 & 1128 \\
\hline Pseudo $R$-sq & 0.59 & 0.51 & 0.40 & 0.58 & 0.55 & 0.55 & 0.56 \\
\hline Chi-sq & 4817.30 & 3418.69 & 154.91 & 203.16 & 810.74 & 1420.43 & 1531.58 \\
\hline
\end{tabular}

This table presents the average marginal effects of logistic regressions. We use a sample of SPAC acquisitions and IPOs that were executed in the period 01/ 2004-12/2015. The dependent variable is a binary variable which equals 1 for SPAC acquisitions and 0 for IPOs. Specification (1) includes our main specification. In Specification (2), we use data derived on the announcement date instead of data after the completion date. In Specification (3), we input expected values for the deal variables. In Specification (4), we match IPO firms to SPAC firms based on size, industry and founding date. In Specifications (5) to (7), we include a dummy for the period after the "tender offer regulation" and its interaction term with VC involvement, PE involvement and time to resolution. All variables are defined in Table 2 and standard errors clustered by country and year are provided in parentheses. We winsorize all deal- and firm-specific variables at the $2 \%$ level. *, **, and ${ }^{* * *}$ indicate statistical significance at the $10 \%, 5 \%$ and $1 \%$ levels, respectively.

IPOs. The dummy variable VC involvement is negatively related to the probability of a SPAC acquisition. This result supports the argument that VCs might prefer the IPO route over the SPAC route for reputational and signaling reasons, even though the latter route may allow them to cash out faster. The weakly significant negative coefficient on PE involvement suggests that PEs prefer IPOs over SPAC acquisitions to sell their stakes as well. Firm-specific variables have an economically important relation to the route through which firms go public. With a one-standard-deviation increase in debt ratio, the probability of going public through a SPAC acquisition increases by 4.37 percentage points. It decreases by 9.35 percentage points and by 7.34 percentage points with a one-standard-deviation increase in the market-to-book asset ratio and size, respectively. The likelihood of a SPAC acquisition is 4.38 percentage points lower with VC involvement and 3.64 percentage points lower with PE involvement. In line with our expectations, the PE effect is significantly smaller than the VC effect.

To sum up, our analysis in Specification 1 shows that SPAC acquisitions are a viable alternative to IPOs for firms that wish to access the public markets in turbulent times when IPOs may be difficult to accomplish. Although there is a cash out advantage associated with SPAC acquisitions, they do not seem to attract profitable and prestigious firms. Rather, our results support the conjecture that firms of lower quality are more likely to use SPAC acquisitions than IPOs. More precisely, our findings indicate 
that small firms that have lower growth opportunities and high leverage and in which VCs and PEs are not involved are more likely to access the public market through the SPAC route.

\subsection{Announcement date data}

One problem with our first regression is that we generate firm-specific variables from the first data that became available after the completion date. The advantage of this procedure is that we are able to obtain all relevant firm-specific information for almost all sample firms. However, as we are interested in comparing the firm-specific variables of potential SPAC firms and IPO firms before they use a particular going-public route, we would prefer using data available at the announcement date. Because most SPAC firms and some IPO firms are not covered by commercial databases before they go public, we have to hand collect the firm-specific variables at the announcement date from individual SEC (proxy statement) filings. We obtain full information for only $81 \%$ of our SPAC firms. The IPO sample size drops by $10 \%$.

In Specification 2, we perform the same regression as in Specification 1 but with the announcement date data (and, consequently, a smaller sample). The results on market- and deal-specific variables do not differ much. The magnitude of firmspecific variables changes, but they all keep their signs and remain, with one exception ( $P E$ involvement), statistically significant. Already in Specification 1, PE involvement was only significant at the $10 \%$ level. Thus, we have to be careful in our interpretations of how PE involvement is related to the likelihood of a SPAC acquisition. All in all, the results make us confident that using completion date data in the main analysis is a reasonable decision.

\subsection{Expected cash out and expected time to resolution}

So far, we use the realized values of the cash out ratio and time to resolution. However, firms may build their preferences regarding the exit route based on expected values of these variables. In Specification 3, we therefore employ a proxy for expected ratios for both deal-specific variables. To model the firm expectations, we use a simple setting where firms base their expectations on historical values. We construct the alternative cash out variable (exp. diff. cash out) for each firm $i$ as the difference in the mean cash out ratio (relative to total assets) between $n$ SPAC acquisitions and $m$ IPOs during the year preceding the particular transaction:

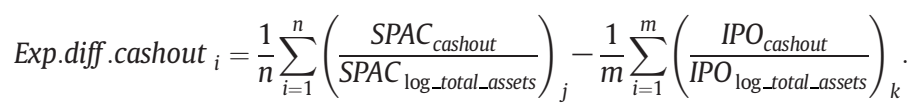

We calculate the alternative time to resolution variable (exp. diff. time to resol.) for each firm $i$ as the difference in time to resolution between $n$ SPAC acquisitions and $m$ IPOs during the year preceding the particular transaction:

$$
\text { Exp.diff.time to resol. }{ }_{i}=\frac{1}{n} \sum_{i=1}^{n}\left(\operatorname{SPAC}_{\text {time to resol. }}\right)_{j}-\frac{1}{m} \sum_{i=1}^{m}\left(\text { IPO }_{\text {time to resol. }}\right)_{k} \text {. }
$$

The positive effect of exp. diff. cash out indicates that existing shareholders favor SPAC acquisitions over IPOs because they expect to sell their holdings more easily. Exp. diff. time to resol. has a positive sign, which suggests that existing firm shareholders expect SPAC acquisitions to take more time until completion in comparison to IPOs. All key variables, except one, have similar effects as in the main regression. Cost of debt, the only exception, becomes insignificant, which suggests that the effect of this variable on the likelihood of a SPAC acquisition should be interpreted with care.

\subsection{Matching}

In our main analysis, we use all SPAC firms and all IPO firms with available data. As we can see in Table 3, an average IPO firm is not comparable to an average SPAC firm. The characteristics of many IPO firms are very different from those of SPAC firms. ${ }^{8}$ We address this concern in Specification 4.

We select those IPO firms that are most similar to our SPAC firms in terms of size, age and industry. More specifically, to each of our 127 SPAC firms, we match the closest IPO firm using a propensity score matching model (without replacement).

Within the SPAC sample and the matched IPO sample, we are able to examine differences in the relevant variables (on which we do not match) while addressing the concerns regarding comparability of IPO firms and SPAC firms. We do not use the matching approach in our main analysis because we are interested, among other things, in firm specific variables (such as size, industry and age) that are related to the way that firms enter public markets. When we match on these variables, we eliminate these effects. This is also the reason that these variables are not included in Specification 4.

We find our results confirmed: all effects we show in the main analysis remain significant. In addition, the variable return on assets, which was insignificant, turns significant at the $5 \%$ level. When we compare firms of similar size and age and within same industries, more profitable firms tend to prefer IPOs.

\footnotetext{
${ }^{8}$ We thank an anonymous referee for raising this concern.
} 


\subsection{Regulation}

The "tender offer regulation" which influences SPACs became effective after the financial crisis and the near dry-out of the SPAC IPO market. SPACs under this reform may choose to abandon the proxy vote in favor of a tender offer. SPAC shareholders who are not satisfied with the acquisition proposal can redeem their shares using the tender offer mechanism. However, there is a certain limit, stated in the SPAC IPO filing, on how many shares can be redeemed during the tender offer (e.g., in the first SPAC under the new structure, 57th Street Acquisition Company, a maximum of $88 \%$ could be redeemed). This reform led to a higher certainty for potential SPAC firms regarding the acquisition outcome. The "tender offer regulation" may speed up the SPAC acquisition process (i.e., reduce time to resolution). For this reason and because the "tender offer regulation" mitigated the uncertainty regarding the acquisition outcome, SPACs might become more attractive to VCs and PEs. To investigate these issues, we interact $V C$ involvement, $P E$ involvement and time to resolution with a regulation dummy. This dummy equals one for the period in which the "tender offer regulation" is effective and zero for the period before. The cut-off date is November 16th 2009, which is the filing date of the first SPAC IPO (57th Street Acquisition Company) that used a tender offer instead of a proxy vote. ${ }^{9}$

We include the interaction terms one-by-one into our main regression and show the results in Specifications 5 to 7. To calculate marginal effects of the interaction terms, we use the technique Ai and Norton (2003) suggest for non-linear models. The VC interaction term in Specification 5 in Table 5 indicates that, after the "tender offer regulation", VCs might consider SPAC acquisitions as a more attractive cash out opportunity than before, albeit this effect is only significant at the $10 \%$ level. For PEs this effect is insignificant (Specification 6). Specification 7 suggests that, in line with our expectations, abandoning the proxy vote in favor of a tender offer speeds up the SPAC acquisition process. Again, this interaction term is only significant at the $10 \%$ level.

Another important regulatory reform during the sample period that affects IPOs and SPACs is the JOBS act. The JOBS act is designed to make it easier and cheaper for young firms (classified as emerging growth companies) to access the public markets through IPOs by relaxing filing and reporting requirements. However, the JOBS act not only made non-SPAC IPOs easier; it also provides SPACs with advantages. SPACs can classify themselves as emerging growth companies and use the advantages that the JOBS act offers. SPACs can not only reduce IPO costs due to lower filing requirements before the SPAC IPO, but they are also burdened with less reporting requirements after the SPAC acquisition (see, e.g., Rodrigues, 2012). Because the JOBS act influences non-SPAC IPOs, SPAC IPOs and SPAC acquisitions in a positive way, the resulting effect on the likelihood of an IPO vs. a SPAC acquisition is unclear.

\section{Long-term performance}

In this section, we investigate how SPAC firms and IPO firms perform in the long term. The evidence so far is consistent with the view that lower-quality firms tend to use SPAC acquisitions to enter the public market, while high-quality firms usually tend to go public via an IPO. Sponsors may push for low-quality firms because if the SPAC becomes liquidated, they lose their promote and their warrants become worthless. It should be noted that SPAC sponsors are allowed to buy SPAC shares with voting rights in the open market prior to the proxy vote, so they may be able to directly influence the outcome of the proxy vote (Jenkinson and Sousa, 2011). The large amount of at-risk capital and the large financial gains in case of a successful acquisition make this a profitable strategy for SPAC sponsors. According to Jog and Sun (2007), SPAC sponsors earn an average of 1900\% annualized returns with SPACs for which the outcome is known (success or failure) during the period 2003 to 2006. Jenkinson and Sousa (2011) show that low-quality acquisitions are approved on a regular basis because some SPAC shareholders, such as hedge funds, promise a positive proxy vote in exchange for additional consideration (Rodrigues and Stegemoller, 2013), particularly before the "tender offer regulation". Finally, some short-term investors may not care about the quality of the target firm, but be only interested in potential profits from bets on the differences between the value of common shares and the value of funds deposited in the trust account.

In general, if low-quality firms enter the public market via a SPAC acquisition, we expect SPAC firms to underperform. Alternatively, it could be the case that SPAC sponsors identify promising targets thanks to their extensive knowledge of the industry, professional experience and valuable business networks (Lewellen, 2009) despite the fact that the selected firms have a poor financial profile at the time of the acquisition. If sponsors can indeed identify firms with hidden potential, i.e., "frogs" that will turn into "princes" in the future, these firms should show superior performance as soon as investors recognize their true quality.

We use two alternative methods to measure long-term performance: event-time analysis and calendar-time analysis. For the event-time analysis, we use buy and hold abnormal returns (Kothari and Warner, 1997). For the calendar-time portfolio analysis, we employ five-factor regression models, which overcome the cross-sectional dependence problem that the event-time approach may entail (Fama, 1998; Mitchell and Stafford, 2000; Datta et al., 2015).

\subsection{Event-time buy and hold abnormal returns}

We calculate buy and hold abnormal returns (BHARs) of SPAC firms and of IPO firms adjusted (i) for the market (Russell 2000 index), (ii) for size and book-to-market and (iii) for the industry. We employ equal-weighted portfolios but value weighting leads

\footnotetext{
${ }^{9}$ Results are similar when we use different cut-off dates, such as: the IPO date of the first SPAC using a tender offer (05/2010), the date when NASDAQ accepted the change to tender offers (12/2011) and the date when AMEX accepted the change to tender offers (01/2011).
} 
to qualitatively similar results. We draw end-of-day stock prices and indices, which include dividends and are adjusted for stock splits, from Capital IQ. We retrieve the return data of 100 size and book-to-market portfolios, 49 industry portfolios and data on book equity and market equity breakpoints from Kenneth R. French's website. ${ }^{10}$ To match our data to these portfolios, we sort SPAC firms, as well as IPO firms, either into 100 different portfolios according to their size and book-to-market breakpoint data or into 49 different portfolios according to their four-digit SIC codes. For size and market equity, we use the month-end market capitalization, and for book-to-market we use the quarter-end book equity after the SPAC acquisition completion or IPO pricing date.

We measure BHARs for periods of 6, 12, 24 and 60 months using the following formula:

$$
\operatorname{BHAR}\left(t_{1}, t_{2}\right)=\prod_{t=t_{1}}^{t_{2}}\left[\left(1+R_{i t}\right)\right]-\prod_{t=t_{1}}^{t_{2}}\left[\left(1+R_{b t}\right)\right],
$$

where $R_{i t}$ is the return on a SPAC firm or an IPO firm and $R_{b t}$ is the return on the benchmark portfolio in $t$. We start calculating BHARs at $t_{1}$, which is the first day of trading for IPO firms or the first day after the completion date for SPAC acquisitions. We only include in the analysis SPAC firms or IPO firms for which return data are available in $t_{1}$. We calculate BHARs until $t_{2}$, which is either the end of our measurement period or the earlier delisting date. In addition to the whole IPO sample, we calculate BHARs for the matched IPO sample, which we describe in Subsection 4.5.

We depict the BHARs for SPAC firms, all IPO firms and matched IPO firms in Table 6. As it is commonly reported in the literature, we also find that the IPO firms significantly underperform the market, the size and book-to-market as well as the industry-matched portfolios (Ritter, 1991; Loughran and Ritter, 1995) in all reported periods. This also holds for firms that go public via a SPAC acquisition. For example, over a 24-month period, SPAC firms underperform the benchmark portfolios by $59 \%, 96 \%$ and $85 \%$ on average. Interestingly, the underperformance of SPAC firms is even stronger than that of IPO firms, and the differences are statistically and economically significant. Over a 24-month period, matched IPO firms underperform their respective portfolios by "only" 34\%, 43\% and 45\%. Moreover, we observe that performance deteriorates over time: for SPAC firms, the six-month market-adjusted BHAR equals - 29\% while the 60-month market-adjusted BHAR amounts to - $102 \%$.

The "tender offer regulation" and the JOBS act that we describe in Subsection 4.6 might have a positive influence on the longterm performance of SPAC firms. The JOBS act could decrease operating costs due to reduced reporting requirements, which in turn might positively influence the long-term performance of SPAC firms. In non-tabulated tests, we compare pre-regulation SPAC BHARs with post-regulation SPAC BHARs but do not find any significant differences for periods of 6, 12 and 24 months. We cannot compare the performance over 60 months because the first SPAC acquisition in the post-regulation subsample occurs on May 5th 2011.

\subsection{Calendar-time five-factor model analysis}

To apply the calendar-time approach, we download monthly values of the three Fama-French factors (Fama and French, 1993) and a momentum factor (Carhart, 1997) from Kenneth R. French's website. ${ }^{11}$ We supplement these data with an aggregated liquidity factor (Pastor and Stambaugh, 2003; Gao and Jain, 2011) retrieved from Lubos Pastor's website. ${ }^{12}$ We then regress monthly calendar-time portfolio excess returns on these five risk factors according to the following specification:

$$
R_{i t}-R_{f t}=\alpha_{i}+\beta_{i}\left(R_{m t}-R_{f t}\right)+s_{i} S M B_{t}+h_{i} H M L_{t}+m_{i} M O M_{t}+l_{i} L I Q_{t}+e_{i t}
$$

where $R_{i t}$ is the return on a portfolio comprising SPAC firms and $R_{f t}$ is the T-bill return, $\alpha_{i}$ captures the portfolio excess return, $R_{m t}$ is the market return on all NYSE/Amex/Nasdaq firms, $S M B_{t}$ is the difference between the return on a portfolio of small firms and a portfolio of large firms, $H M L_{t}$ is the difference between the return on high book-to-market and low book-to-market stocks, $M O M_{t}$ is the difference between the return on high-prior-return portfolios and low-prior-return portfolios and $L I Q_{t}$ is the difference between the return on low-turnover portfolios and high-turnover portfolios. We use equal-weighted returns. A three-factor model and/or value-weighted returns yield qualitatively similar results. The results for periods of $6,12,24$ and 60 months are depicted in Table 7 in Specifications 1 to 4 . Consistent with the BHAR analyses, these results show that SPAC firms underperform the market after going public. They have significant and negative alphas in all periods under consideration.

We perform the same analyses for both all and matched IPO firms and present the results in Specifications 5 to 8 and 9 to 12 , respectively. Both all and matched IPO firms underperform as well, but the underperformance of SPAC firms is again larger. For example, over a 24-month period, SPAC firms have a monthly alpha of $-5.2 \%$, whereas the monthly alphas for all and matched IPO firms reach $-1.2 \%$ and $-1.7 \%$, respectively.

Finally, in Table 8 we present results for hedged portfolios. A hedged portfolio consists of a long position in an IPO equalweighted portfolio and a short position in a SPAC equal-weighted portfolio. Specifications 1 to 4 depict the results for the

\footnotetext{
10 http://mba.tuck.dartmouth.edu/pages/faculty/ken.french/data_library.html.

11 http://mba.tuck.dartmouth.edu/pages/faculty/ken.french/data_library.html.

12 http://faculty.chicagobooth.edu/lubos.pastor/research.
} 


\begin{tabular}{|c|c|c|c|c|c|c|c|c|c|c|c|c|c|}
\hline & \multirow{2}{*}{\multicolumn{3}{|c|}{ SPAC BHARs }} & \multicolumn{5}{|c|}{ Whole sample } & \multicolumn{5}{|c|}{ Matched sample } \\
\hline & & & & \multicolumn{3}{|l|}{ IPO BHARs } & \multirow{2}{*}{$\begin{array}{l}\text { WMW Test } \\
z \text {-Value }\end{array}$} & \multirow{2}{*}{$\begin{array}{l}t \text {-Test } \\
t \text {-Value }\end{array}$} & \multicolumn{3}{|l|}{ IPO BHARs } & \multirow{2}{*}{$\begin{array}{l}\text { WMW Test } \\
z \text {-Value }\end{array}$} & \multirow{2}{*}{$\begin{array}{l}t \text {-Test } \\
t \text {-Value }\end{array}$} \\
\hline & Median & Mean & $N$ & Median & Mean & $N$ & & & Median & Mean & $N$ & & \\
\hline \multicolumn{14}{|l|}{6 months } \\
\hline Market adjusted & $-0.28^{* * *}$ & $-0.29^{* * *}$ & 109 & $-0.07^{* * *}$ & $-0.06^{* * *}$ & 1112 & $5.89^{* * *}$ & $6.48^{* * *}$ & $-0.13^{* * *}$ & -0.06 & 113 & $3.92^{* * *}$ & $4.50^{\text {**** }}$ \\
\hline Size E btm adjusted & $-0.30^{* * *}$ & $-0.32^{* * *}$ & 92 & $-0.10^{* * *}$ & $-0.07^{* * *}$ & 1046 & $5.56^{* * *}$ & $5.57^{* * *}$ & $-0.16^{* * *}$ & $-0.09^{*}$ & 104 & $3.49^{* * *}$ & $3.96^{* * *}$ \\
\hline Industry adjusted & $-0.31^{* * *}$ & $-0.34^{* * *}$ & 109 & $-0.10^{* * *}$ & $-0.08^{* * *}$ & 1100 & $6.36^{* * *}$ & $6.66^{* * *}$ & $-0.17^{* * *}$ & $-0.09^{*}$ & 111 & $4.04^{* * *}$ & $4.64^{* * * *}$ \\
\hline \multicolumn{14}{|l|}{12 months } \\
\hline Market adjusted & $-0.46^{* * *}$ & $-0.46^{* * *}$ & 109 & $-0.15^{* * *}$ & $-0.08^{* * *}$ & 1082 & $7.40^{* * *}$ & $8.29^{* * *}$ & $-0.17^{* * *}$ & $-0.12^{* *}$ & 110 & $4.75^{* * *}$ & $4.96^{* * *}$ \\
\hline Size E' btm adjusted & $-0.58^{* * *}$ & $-0.57^{* * *}$ & 92 & $-0.16^{* * *}$ & $0.10^{* * *}$ & 1021 & $7.53^{* * *}$ & $7.59^{* * *}$ & $-0.18^{* * *}$ & $-0.14^{* *}$ & 101 & $4.88^{* * *}$ & $5.14^{* * * *}$ \\
\hline Industry adjusted & $-0.51^{* * *}$ & $-0.57^{* * *}$ & 109 & $-0.18^{* * *}$ & $-0.13^{* * *}$ & 1070 & $7.91^{* * *}$ & $8.59^{* * *}$ & $-0.23^{* * *}$ & $-0.15^{*}$ & 108 & $5.13^{* * *}$ & $5.59^{* * * *}$ \\
\hline $\begin{array}{l}24 \text { months } \\
\text { Market adjusted }\end{array}$ & $-0.56^{* * *}$ & $-0.59^{* * *}$ & 104 & $-0.30^{* * *}$ & $-0.21^{* * *}$ & 969 & $6.22^{* * *}$ & $7.11^{* * *}$ & $-0.35^{* * *}$ & $-0.34^{* * *}$ & 108 & $3.36^{* * *}$ & $3.23^{* * *}$ \\
\hline Size E' btm adjusted & $-0.92^{* * *}$ & $-0.96^{* * *}$ & 87 & $-0.39^{* * *}$ & $-0.30^{* * * *}$ & 914 & $7.27^{* * *}$ & $6.88^{* * *}$ & $-0.43^{* * *}$ & $-0.43^{* * *}$ & 99 & $4.71^{* * *}$ & $4.77^{\text {**** }}$ \\
\hline Industry adjusted & $-0.88^{* * *}$ & $-0.85^{* * *}$ & 104 & $-0.44^{* * *}$ & $-0.36^{* * *}$ & 958 & $7.01^{* * *}$ & $7.17^{* * *}$ & $-0.54^{* * *}$ & $-0.45^{* * *}$ & 106 & $4.29^{* * *}$ & $4.34^{* * *}$ \\
\hline \multicolumn{14}{|l|}{60 months } \\
\hline Market adjusted & $-0.90^{* * *}$ & $-1.02^{* * *}$ & 88 & $-0.58^{* * *}$ & -0.20 & 704 & $7.47^{* * *}$ & $4.01^{* * *}$ & $-0.69^{* * *}$ & $-0.37^{*}$ & 84 & $4.87^{* * *}$ & $3.82^{* * *}$ \\
\hline Size E' btm adjusted & $-2.07^{* * *}$ & $-2.48^{* * *}$ & 76 & $-1.05^{* * *}$ & $-0.79^{*}$ & 666 & $9.14^{* * *}$ & $5.88^{* * *}$ & $-1.29^{* * *}$ & $-1.01^{* *}$ & 78 & $6.01^{* * *}$ & $5.56^{* * *}$ \\
\hline Industry adjusted & $-1.72^{* * *}$ & $-1.80^{* * *}$ & 88 & $-1.25^{* * *}$ & $-0.98^{* *}$ & 695 & $5.62^{* * *}$ & $3.75^{* * *}$ & $-1.25^{* * *}$ & $-1.13^{* * *}$ & 83 & $3.79^{* * *}$ & $3.58^{* * *}$ \\
\hline
\end{tabular}

This table presents median and mean (log) BHARs of SPAC acquisitions and IPOs executed in the period 01/2004-12/2015 over 6, 12, 24 and 60 months and their significances. It also shows the values and significances of the Wilcoxon-Mann-Whitney (WMW) test and $t$-test we run to compare BHARs between SPAC acquisitions and all as well as matched IPOs. *, **, and ${ }^{* * *}$ indicate statistical significance at the $10 \%, 5 \%$ and $1 \%$ levels, respectively.

whole IPO sample and Specifications 5 to 8 for the matched IPO sample. The results confirm that SPAC firms significantly underperform IPO firms in all periods.

Looking at the long-term performance of SPAC firms appears to confirm the picture that emerges during the first part of our empirical analysis; namely, that SPACs attract lower-quality firms. In the months and years following the SPAC acquisition, investors seem to recognize the lower quality of SPAC firms and punish these firms in the long term. Consequently, long-term investors that put their money in SPACs at the completion date systematically underperform the market, industry and similar non-SPAC firms as well as IPO firms.

\section{Summary and conclusion}

Cash-shell companies suffered a poor reputation after several cases of fraud involving these vehicles during the 1980s. This led to the introduction of new legislation that aimed to increase the transparency of cash-shell companies, improve their shareholder rights and motivate their sponsors to act in the interests of the shareholders. These changes might contribute to a wave of newgeneration SPACs, which started in the second half of 2003. The purpose of this paper is to shed light on these new-generation SPACs, to investigate whether SPAC acquisitions are a viable alternative to IPOs for private firms aiming to achieve a public listing and to assess their performance.

Our findings indicate that SPAC acquisitions allow firms to enter public markets in difficult times when it is hard to access the IPO channel. They also turn out to be beneficial to the existing SPAC firm shareholders that realize higher cash out ratios than they would obtain through an IPO. However, the results support the view that the firms that SPACs attract are not as appealing as those that chose an IPO. More specifically, our results lend support to the hypothesis that firms that enter public markets via a SPAC acquisition have lower growth opportunities, are more highly levered and smaller than IPO firms. They are also less likely to receive investments from VCs and private equity funds. Moreover, our findings suggest that SPAC acquisitions may take longer to execute than IPOs - at least, this seems to be the case until the SPAC structure was modified in 2010.

Looking at the long-term performance of SPAC firms, we find that they severely underperform the market, industry and firms of similar sizes and book-to-market ratios as well as IPO firms. This result is consistent over different methodologies and time horizons. On that basis, we therefore conclude that the "frog turned prince" scenario does not apply in the case of SPAC firms: these firms remain "frogs" in the long term.

Over the last few years, SPAC activity has caught up again and, in April 2016, Ellenoff Grossman \& Schole, a law firm that specializes in this vehicle, stated, "SPACs are back" ${ }^{13}$ In the first three months in 2016, three SPACs with a total volume of US\$569 million went public, whereas the total IPO volume only equaled US $\$ 444$ million. ${ }^{14}$ In April 2016, CF Corporation filed for a US $\$ 600$ million SPAC IPO, which would make it the largest SPAC IPO since 2008. Major investment banks show interest in SPACs. As an example, Goldman Sachs advised its first SPAC IPO, Silver Run Acquisition Corporation, in February 2016, which is also Goldman's largest IPO assignment in 2016 by end of March. ${ }^{15}$ These developments are astonishing given the poor long-term performance

\footnotetext{
13 http://www.egsllp.com/news/resources/spacs.

14 Source: Capital IQ.

15 http://www.reuters.com/article/us-banks-spacs-dealtalk-idUSKCNOWQOCO.
} 
Table 7

Factor regressions - market portfolio.

\begin{tabular}{|c|c|c|c|c|c|c|c|c|c|c|c|c|}
\hline & \multicolumn{4}{|l|}{ All SPACs } & \multicolumn{4}{|l|}{ All IPOs } & \multicolumn{4}{|c|}{ Matched IPOs } \\
\hline & $\begin{array}{l}\text { (1) } \\
6 \text { months }\end{array}$ & $\begin{array}{l}(2) \\
12 \text { months }\end{array}$ & $\begin{array}{l}\text { (3) } \\
24 \text { months }\end{array}$ & $\begin{array}{l}(4) \\
60 \text { months }\end{array}$ & $\begin{array}{l}(5) \\
6 \text { months }\end{array}$ & $\begin{array}{l}(6) \\
12 \text { months }\end{array}$ & $\begin{array}{l}\text { (7) } \\
24 \text { months }\end{array}$ & $\begin{array}{l}(8) \\
60 \text { months }\end{array}$ & $\begin{array}{l}(9) \\
6 \text { months }\end{array}$ & $\begin{array}{l}(10) \\
12 \text { months }\end{array}$ & $\begin{array}{l}(11) \\
24 \text { months }\end{array}$ & $\begin{array}{l}(12) \\
60 \text { months }\end{array}$ \\
\hline Intercept $(\alpha)$ & $\begin{array}{l}-0.0510^{* * *} \\
(0.0096)\end{array}$ & $\begin{array}{l}-0.0533^{* * *} \\
(0.0076)\end{array}$ & $\begin{array}{l}-0.0521^{* * *} \\
(0.0067)\end{array}$ & $\begin{array}{l}-0.0416^{* * * *} \\
(0.0056)\end{array}$ & $\begin{array}{l}-0.0116^{* * *} \\
(0.0035)\end{array}$ & $\begin{array}{l}-0.0114^{* * *} \\
(0.0028)\end{array}$ & $\begin{array}{l}-0.0120^{* * *} \\
(0.0027)\end{array}$ & $\begin{array}{l}-0.0134^{* * *} \\
(0.0024)\end{array}$ & $\begin{array}{l}-0.0071 \\
(0.0071)\end{array}$ & $\begin{array}{l}-0.0102^{*} \\
(0.0054)\end{array}$ & $\begin{array}{l}-0.0169^{* * * *} \\
(0.0051)\end{array}$ & $\begin{array}{l}-0.0195^{* * *} \\
(0.0044)\end{array}$ \\
\hline RMRF & $\begin{array}{l}1.3087^{* * *} \\
(0.2471)\end{array}$ & $\begin{array}{l}0.8408^{* * * *} \\
(0.1999)\end{array}$ & $\begin{array}{l}0.7596^{* * *} \\
(0.1749)\end{array}$ & $\begin{array}{l}1.0636^{* * *} \\
(0.1479)\end{array}$ & $\begin{array}{l}0.9823^{* * *} \\
(0.0908)\end{array}$ & $\begin{array}{l}1.0016^{* * *} \\
(0.0746)\end{array}$ & $\begin{array}{l}1.1291 * * * \\
(0.0710)\end{array}$ & $\begin{array}{l}1.1523^{* * *} \\
(0.0624)\end{array}$ & $\begin{array}{l}0.9892^{* * *} \\
(0.2003)\end{array}$ & $\begin{array}{l}0.8990 * * * \\
(0.1444)\end{array}$ & $\begin{array}{l}1.2216^{* * * *} \\
(0.1333)\end{array}$ & $\begin{array}{l}1.2840^{* * *} \\
(0.1160)\end{array}$ \\
\hline$S M B$ & $\begin{array}{l}0.3655 \\
(0.4241)\end{array}$ & $\begin{array}{l}0.1291 \\
(0.3384)\end{array}$ & $\begin{array}{l}-0.0828 \\
(0.2950)\end{array}$ & $\begin{array}{l}-0.1603 \\
(0.2495)\end{array}$ & $\begin{array}{l}0.8377^{* * *} \\
(0.1532)\end{array}$ & $\begin{array}{l}0.8407^{* * * *} \\
(0.1258)\end{array}$ & $\begin{array}{l}0.7723^{* * * *} \\
(0.1197)\end{array}$ & $\begin{array}{l}0.8164 * * * \\
(0.1052)\end{array}$ & $\begin{array}{l}0.9201^{* * * *} \\
(0.3204)\end{array}$ & $\begin{array}{l}0.8999^{* * *} \\
(0.2419)\end{array}$ & $\begin{array}{l}0.7117^{* * * *} \\
(0.2249)\end{array}$ & $\begin{array}{l}0.6651^{* * *} \\
(0.1956)\end{array}$ \\
\hline HML & $\begin{array}{l}-0.2819 \\
(0.4160)\end{array}$ & $\begin{array}{l}-0.0858 \\
(0.3345)\end{array}$ & $\begin{array}{l}-0.1562 \\
(0.2933)\end{array}$ & $\begin{array}{l}-0.2774 \\
(0.2481)\end{array}$ & $\begin{array}{l}-0.5898^{* * *} \\
(0.1523)\end{array}$ & $\begin{array}{l}-0.4749^{* * *} \\
(0.1251)\end{array}$ & $\begin{array}{l}-0.5020^{* * *} \\
(0.1191)\end{array}$ & $\begin{array}{l}-0.1960^{*} \\
(0.1046)\end{array}$ & $\begin{array}{l}-0.4745 \\
(0.3477)\end{array}$ & $\begin{array}{l}-0.5642^{* *} \\
(0.2415)\end{array}$ & $\begin{array}{l}-0.0503 \\
(0.2236)\end{array}$ & $\begin{array}{l}0.0449 \\
(0.1945)\end{array}$ \\
\hline MOM & $\begin{array}{l}0.1516 \\
(0.2085)\end{array}$ & $\begin{array}{l}-0.1551 \\
(0.1683)\end{array}$ & $\begin{array}{l}-0.1471 \\
(0.1474)\end{array}$ & $\begin{array}{l}-0.2561^{* *} \\
(0.1246)\end{array}$ & $\begin{array}{l}0.1028 \\
(0.0765)\end{array}$ & $\begin{array}{l}-0.0108 \\
(0.0629)\end{array}$ & $\begin{array}{l}-0.1467^{* *} \\
(0.0598)\end{array}$ & $\begin{array}{l}-0.1728^{* * *} \\
(0.0526)\end{array}$ & $\begin{array}{l}0.1365 \\
(0.2016)\end{array}$ & $\begin{array}{l}0.0126 \\
(0.1530)\end{array}$ & $\begin{array}{l}-0.0899 \\
(0.1123)\end{array}$ & $\begin{array}{l}-0.2357^{* *} \\
(0.0977)\end{array}$ \\
\hline LIQ & $\begin{array}{l}-0.0175 \\
(0.1366)\end{array}$ & $\begin{array}{l}0.1535 \\
(0.1096)\end{array}$ & $\begin{array}{l}0.1095 \\
(0.0960)\end{array}$ & $\begin{array}{l}0.1072 \\
(0.0812)\end{array}$ & $\begin{array}{l}0.1595^{* * * *} \\
(0.0499)\end{array}$ & $\begin{array}{l}0.1444^{* * * *} \\
(0.0409)\end{array}$ & $\begin{array}{l}0.1145^{* * * *} \\
(0.0390)\end{array}$ & $\begin{array}{l}0.1003^{* * *} \\
(0.0342)\end{array}$ & $\begin{array}{l}0.2066^{*} \\
(0.1081)\end{array}$ & $\begin{array}{l}0.1209 \\
(0.0778)\end{array}$ & $\begin{array}{l}0.1146 \\
(0.0732)\end{array}$ & $\begin{array}{l}0.0231 \\
(0.0637)\end{array}$ \\
\hline Adjusted $R$-sq & 0.23 & 0.19 & 0.17 & 0.38 & 0.66 & 0.75 & 0.80 & 0.85 & 0.32 & 0.41 & 0.57 & 0.66 \\
\hline
\end{tabular}

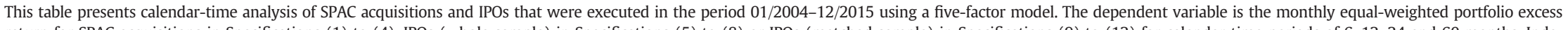

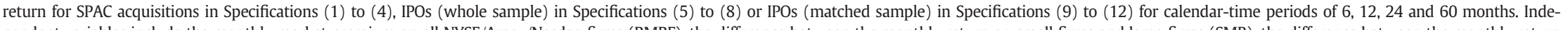

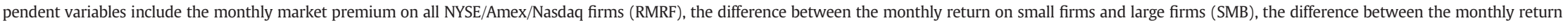

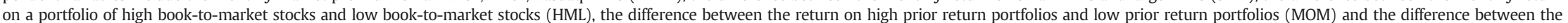
return of low-turnover portfolios and high-turnover portfolios (LIQ). Standard errors are provided in parentheses. *, **, and ${ }^{* * *}$ indicate statistical significance at the $10 \%, 5 \%$ and $1 \%$ levels, respectively. 
Table 8

Factor regressions - hedged portfolio.

\begin{tabular}{|c|c|c|c|c|c|c|c|c|}
\hline & \multicolumn{4}{|c|}{ All IPOs-all SPACs } & \multicolumn{4}{|c|}{ Matched IPOs-all SPACs } \\
\hline & $\begin{array}{l}(1) \\
6 \text { months }\end{array}$ & $\begin{array}{l}(2) \\
12 \text { months }\end{array}$ & $\begin{array}{l}\text { (3) } \\
24 \text { months }\end{array}$ & $\begin{array}{l}(4) \\
60 \text { months }\end{array}$ & $\begin{array}{l}(5) \\
6 \text { months }\end{array}$ & $\begin{array}{l}(6) \\
12 \text { months }\end{array}$ & $\begin{array}{l}\text { (7) } \\
24 \text { months }\end{array}$ & $\begin{array}{l}(8) \\
60 \text { months }\end{array}$ \\
\hline Intercept $(\alpha)$ & $\begin{array}{l}0.0395^{* * *} \\
(0.0094)\end{array}$ & $\begin{array}{l}0.0422^{* * *} \\
(0.0075)\end{array}$ & $\begin{array}{l}0.0400^{* * *} \\
(0.0059)\end{array}$ & $\begin{array}{l}0.0281^{* * * *} \\
(0.0049)\end{array}$ & $\begin{array}{l}0.0422^{* * * *} \\
(0.0115)\end{array}$ & $\begin{array}{l}0.0414^{* * *} \\
(0.0089)\end{array}$ & $\begin{array}{l}0.0352^{* * *} \\
(0.0071)\end{array}$ & $\begin{array}{l}0.0221^{* * *} \\
(0.0059)\end{array}$ \\
\hline$R M R F$ & $\begin{array}{l}-0.3596 \\
(0.2414)\end{array}$ & $\begin{array}{l}0.1650 \\
(0.1954)\end{array}$ & $\begin{array}{l}0.3695^{* *} \\
(0.1547)\end{array}$ & $\begin{array}{l}0.0887 \\
(0.1279)\end{array}$ & $\begin{array}{l}-0.2092 \\
(0.3210)\end{array}$ & $\begin{array}{l}0.0921 \\
(0.2368)\end{array}$ & $\begin{array}{l}0.4620^{* *} \\
(0.1879)\end{array}$ & $\begin{array}{l}0.2204 \\
(0.1559)\end{array}$ \\
\hline$S M B$ & $\begin{array}{l}0.5190 \\
(0.4144)\end{array}$ & $\begin{array}{l}0.7004^{* *} \\
(0.3308)\end{array}$ & $\begin{array}{l}0.8550^{* * * *} \\
(0.2609)\end{array}$ & $\begin{array}{l}0.9767^{* * *} \\
(0.2156)\end{array}$ & $\begin{array}{l}0.2277 \\
(0.5249)\end{array}$ & $\begin{array}{l}0.7026^{*} \\
(0.3987)\end{array}$ & $\begin{array}{l}0.7945^{* *} \\
(0.3168)\end{array}$ & $\begin{array}{l}0.8254^{* * *} \\
(0.2629)\end{array}$ \\
\hline$H M L$ & $\begin{array}{l}-0.3219 \\
(0.4065)\end{array}$ & $\begin{array}{l}-0.3867 \\
(0.3270)\end{array}$ & $\begin{array}{l}-0.3458 \\
(0.2595)\end{array}$ & $\begin{array}{l}0.0814 \\
(0.2144)\end{array}$ & $\begin{array}{l}-0.2713 \\
(0.5644)\end{array}$ & $\begin{array}{l}-0.3847 \\
(0.3950)\end{array}$ & $\begin{array}{l}0.1059 \\
(0.3151)\end{array}$ & $\begin{array}{l}0.3223 \\
(0.2615)\end{array}$ \\
\hline MOM & $\begin{array}{l}-0.0492 \\
(0.2037)\end{array}$ & $\begin{array}{l}0.1473 \\
(0.1645)\end{array}$ & $\begin{array}{l}0.0005 \\
(0.1304)\end{array}$ & $\begin{array}{l}0.0834 \\
(0.1077)\end{array}$ & $\begin{array}{l}0.0574 \\
(0.3362)\end{array}$ & $\begin{array}{l}0.2334 \\
(0.2511)\end{array}$ & $\begin{array}{l}0.0572 \\
(0.1583)\end{array}$ & $\begin{array}{l}0.0204 \\
(0.1314)\end{array}$ \\
\hline LIQ & $\begin{array}{l}0.1921 \\
(0.1335)\end{array}$ & $\begin{array}{l}-0.0076 \\
(0.1071)\end{array}$ & $\begin{array}{l}0.0050 \\
(0.0849)\end{array}$ & $\begin{array}{l}-0.0069 \\
(0.0702)\end{array}$ & $\begin{array}{l}0.1694 \\
(0.1750)\end{array}$ & $\begin{array}{l}-0.0341 \\
(0.1274)\end{array}$ & $\begin{array}{l}0.0051 \\
(0.1031)\end{array}$ & $\begin{array}{l}-0.0841 \\
(0.0856)\end{array}$ \\
\hline$R$-sq & 0.04 & 0.07 & 0.17 & 0.18 & 0.02 & 0.05 & 0.15 & 0.15 \\
\hline
\end{tabular}

This table presents calendar-time analysis of SPAC acquisitions and IPOs that were executed in the period 01/2004-12/2015 using a five-factor model. The dependent variable is the monthly equal-weighted portfolio return for IPOs minus the monthly equal-weighted portfolio return for SPAC acquisitions. In Specifications (1) to (4), we use the whole IPO sample and in Specifications (5) to (8) we use the matched IPO sample. Independent variables include the monthly market premium on all NYSE/Amex/Nasdaq firms (RMRF), the difference between the monthly return on small firms and large firms (SMB), the difference between the monthly return on a portfolio of high book-to-market stocks and low book-to-market stocks (HML), the difference between the return on high prior return portfolios and low prior return portfolios (MOM) and the difference between the return of low-turnover portfolios and high-turnover portfolios (LIQ). Standard errors are provided in parentheses. *, **, and *** indicate statistical significance at the $10 \%, 5 \%$ and $1 \%$ levels respectively.

and the relatively low quality of SPAC firms, which we document in this paper. We therefore believe that further research is needed to understand why SPACs are getting popular again. Such research would, for example, investigate the role of intermediaries, such as investment banks or law firms.

\section{Acknowledgements}

We would like to thank an anonymous referee and the editor for valuable feedback and are grateful to Nihat Aktas, Jaap Bos, Robert Jung, William Megginson, Stefan Ruenzi, Christian Schlag and Eric Theissen for their detailed and insightful comments. We also thank the participants in the seminars and discussions that were held during the WHU Research Seminar in Finance and Accounting (Vallendar, 2015), the 23rd Annual Meeting of the European Financial Management Association (Rome, 2014), the Financial Management Association European Conference (Maastricht, 2014) and the 20th Annual Meeting of the German Finance Association (Wuppertal, 2013). We gratefully acknowledge access to Capital IQ Compustat US, SDC Platinum and Thomson One Private Equity provided by DALAHO, University of Hohenheim. Edgar Epners provided provided valuable research assistance. This research did not receive any specific grant from funding agencies in the public, commercial, or not-for-profit sectors.

\section{References}

Adjei, F., Cyree, K.B., Walker, M.M., 2008. The determinants and survival of reverse mergers vs. IPOs. J. Econ. Finance 32, $176-194$.

Ai, C., Norton, E.C., 2003. Interaction terms in logit and probit models. Econ. Lett. 80, 123-129.

Aydogdu, M., Shekhar, C., Torbey, V., 2007. Shell companies as IPO alternatives: an analysis of trading activity around reverse mergers. Appl. Financ. Econ. 17, $1335-1347$.

Barry, C.B., Muscarella, C.J., Peavy III, J.W., Vetsuypens, M.R., 1990. The role of venture capital in the creation of public companies: evidence from the going-public process. J. Financ. Econ. 27, 447-471.

Bascha, A., Walz, U., 2001. Convertible securities and optimal exit decisions in venture capital finance. J. Corp. Finance 7, $285-306$.

Bayar, O., Chemmanur, T.J., 2011. IPOs versus acquisitions and the valuation premium puzzle: a theory of exit choice by entrepreneurs and venture capitalists. J. Financ. Quant. Anal. 46, 1755-1793.

Benveniste, L.M., Spindt, P.A., 1989. How investment bankers determine the offer price and allocation of new issues. J. Financ. Econ. 24, 343-361.

Berger, R., 2008. SPACs: an alternative way to access the public markets. J. Appl. Corp. Finance 20, 68-75.

Bradley, D.J., Jordan, B.D., Yi, H.-C., Roten, I.C., 2001. Venture capital and IPO lockup expiration: an empirical analysis. J. Financ. Res. $24,465-494$.

Brau, J.C., Francis, B., Kohers, N., 2003. The choice of IPO versus takeover: empirical evidence. J. Bus. 76, 583-612.

Brav, A., Gompers, P.A., 2003. The role of lockups in initial public offerings. Rev. Financ. Stud. 16, 1-29.

Brown, P.R., Ferguson, A., Lam, P., 2013. Choice Between Alternative Routes to Go Public: Backdoor Listing Versus IPO, Handbook of Research on IPO. Edward Elgar Publishing, Cheltenham, UK; Northampton, USA.

Carhart, M.M., 1997. On persistence in mutual fund performance. J. Financ. 52, 57-82.

Chung, K.H., Pruitt, S.W., 1994. A simple approximation of Tobin's q. Financ. Manag. 23, 70-74.

Cumming, D., Haß, L.H., Schweizer, D., 2014. The fast track IPO - success factors for taking firms public with SPACs. J. Bank. Financ. 47, 198-213.

Datar, V., Emm, E., Ince, U., 2012. Going public through the back door: a comparative analysis of SPACs and IPOs. Bank. Finance Rev. 4, 17-36.

Datta, S., Gruskin, M., Iskandar-Datta, M., 2015. On post-IPO stock price performance: a comparative analysis of RLBOs and IPOs. J. Bank. Financ. 55, 187-203.

Fama, E.F., 1998. Market efficiency, long-term returns, and behavioral finance. J. Financ. Econ. 49, $283-306$.

Fama, E.F., French, K.R., 1993. Common risk factors in the returns on stocks and bonds. J. Financ. Econ. 33, 3-56.

Fang, L.H., 2005. Investment bank reputation and the price and quality of underwriting services. J. Financ. 60, 2729-2761. 
Feldman, D.N., 2010. Reverse Mergers: And Other Alternatives to Traditional IPOs. Bloomberg Press, New York. Floros, I.V., Sapp, T.R., 2011. Shell games: on the value of shell companies. J. Corp. Finance 17, 850-867.

Gao, N., Jain, B.A., 2011. Founder CEO management and the long-run investment performance of IPO firms. J. Bank. Financ. 35, 1669-1682.

Giot, P., Schwienbacher, A., 2007. IPOs, trade sales and liquidations: modelling venture capital exits using survival analysis. J. Bank. Financ. 31, 679-702.

Gleason, K.C., Rosenthal, L., Wiggins III, R.A., 2005. Backing into being public: an exploratory analysis of reverse takeovers. J. Corp. Finance 12, 54-79.

Gleason, K.C., Jain, R., Rosenthal, L., 2008. Alternatives for going public: evidence from reverse takeovers, self-underwritten IPOs, and traditional IPOs. J. Financ. Strateg. Decisions 1, 1-24.

Gompers, P.A., 1996. Grandstanding in the venture capital industry. J. Financ. Econ. 42, 133-156.

Gompers, P., Lerner, J., 2001. The venture capital revolution. J. Econ. Perspect. 15, 145-168.

Greene, D., 2016. The wealth of private firm owners following reverse mergers. J. Corp. Finance 37, 56-75.

Hale, L.M., 2007. SPAC: a financing tool with something for everyone. J. Corp. Account. Finance 18, 67-74.

Jenkinson, T., Sousa, M., 2011. Why SPAC investors should listen to the market. J. Appl. Finance. 21, 38-57.

Jog, V., Sun, C., 2007. Blank Check IPOs: A Home Run for Management. (available at SSRN) http://ssrn.com/abstract=1018242.

Kothari, S.P., Warner, J.B., 1997. Measuring long-horizon security price performance. J. Financ. Econ. 43, 301-339.

Lakicevic, M., Vulanovic, M., 2013. A story on SPACs. Manag. Financ. 39, 384-403.

Lakicevic, M., Shachmurove, Y., Vulanovic, M., 2014. Institutional changes of specified purpose acquisition companies (SPACs). N. Am. J. Econ. Finance. 28, 149-169.

Lee, I., Lochhead, S., Ritter, J., Zhao, Q., 1996. The costs of raising capital. J. Financ. Res. 19, 59-74.

Lewellen, S., 2009. SPACs as an Asset Class. (available at SSRN) http://ssrn.com/abstract=1284999.

Loughran, T., Ritter, J.R., 1995. The new issues puzzle. J. Financ. 50, 23-51.

Megginson, W.L., Weiss, K.A., 1991. Venture capitalist certification in initial public offerings. J. Financ. 46, 879-903.

Mitchell, M.L., Stafford, E., 2000. Managerial decisions and long-term stock price performance. J. Bus. 73, $287-329$.

Nahata, R., 2008. Venture capital reputation and investment performance. J. Financ. Econ. 90, 127-151.

Pastor, L., Stambaugh, R.F., 2003. Liquidity risk and expected stock returns. J. Polit. Econ. 111, 642-685.

Phalippou, L., Gottschalg, O., 2009. The performance of private equity funds. Rev. Financ. Stud. 22, 1747-1776.

Poulsen, A.B., Stegemoller, M., 2008. Moving from private to public ownership: selling out to public firms versus initial public offerings. Financ. Manag. 37, 81-101. Ritter, J.R., 1991. The long-run performance of initial public offerings. J. Financ. 46, 3-27.

Ritter, J.R., 2016. Initial Public Offerings: Updated Statistics. University of Florida.

Ritter, J.R., Welch, I., 2002. A review of IPO activity, pricing, and allocations. J. Financ. 57, 1795-1828.

Rodrigues, U., 2012. SPACs and the JOBS act. Harv. Bus. Law Rev. 17-21.

Rodrigues, U., Stegemoller, M., 2011. Special Purpose Acquisition Corporations: A Public View of Private Equity. UGA Legal Studies Research Paper. pp. 11-12.

Rodrigues, U., Stegemoller, M., 2013. Exit, voice, and reputation: the evolution of SPACs. Del. J. Corp. Law 37, 849-929.

Rodrigues, U., Stegemoller, M., 2014. What all-cash companies tell us about IPOs and acquisitions. J. Corp. Finance 29, 111-121.

Schill, M.J., 2004. Sailing in rough water: market volatility and corporate finance. J. Corp. Finance 10, 659-681.

SEC, 2005. Use of Form S-8, Form 8-K, and Form 20-F by Shell Companies. (available at) http://sec.gov/rules/final/33-8587.pdf. 